\title{
Pendent Jurisdiction and the Eleventh Amendment
}

\author{
John P. Dwyer $\dagger$
}

Institutional reform litigation has become a regular feature of the district court docket. Numerous federal courts liave ordered detailed, affirmative relief against state officials to remedy conditions in state institutions violating riglits under both the fourteentli amendment ${ }^{1}$ and federal and state statutes. In many cases, the federal courts have taken on the task of managing state institutions subject to the court decree. ${ }^{2}$

Because the formulation and implementation of imstitutional reform decrees pose novel threats to state sovereignty, the Supreme Court has been somewliat anbivalent toward this type of litigation. Altliougli the Court lias stated its willingness to use the power of the federal courts to remedy illegal mstitutional conditions, ${ }^{3}$ it also has developed doctrines restricting the availability of this type of relief. ${ }^{4}$

The Court's decision in Pennhurst State School \& Hospital v. Hald-

$\dagger$ Acting Professor of Law, Boalt Hall School of Law, University of California, Berkeley. B.A. 1973, DePauw University; Ph.D. 1978, California Institute of Technology; J.D. 1980, Boalt Hall School of Law, University of California, Berkeley.

I am indebted to a number of friends and colleagues for their helpful criticisnus and assistance in the course of writing this Article. Jesse Choper, Jack Coons, Martin Shapiro, Harry Scheiber, and Preble Stolz read an earlier draft and made niany useful suggestions. Steve Bundy was helpful in discussing certain procednral issues. Michael Smith and Willy Fletcher generously took the tine to ntake extended comments, improving the end product considerably. Linda Helyar, Beverly Alexander, and Ellen Garber provided able research assistance and helpful criticisms on different versions of this Article.

I owe nyy greatest debt to Paul Mishkin, with whom I began a larger version of this Article as a joint project almost two years ago. Since then, he has spent uncountable hours discussing our ideas and reading iny nuanuscripts. This Article is inarked nidelibly with his ideas and contributions.

1. The fourtecnth amendment provides in part:

Section 1. [N] or shall any State deprive any person of life, liberty, or property, without due process of law; nor deny to any person within its jurisdiction the equal protection of the laws..... Section 5. The Congress shall have power to enforce, by appropriate legislation, the provisions of this article.

U.S. CoNST. amend. XIV, $\S \S 2,5$.

2. See, e.g., Note, The Wyatt Case: Implementation of a Judicial Decree Ordering Institutional Change, 84 YALE L.J. 1338, 1352-78 (1975) (describing implementation of a decree remedying conditions in Alabama's nental health facilities).

3. Rhodes v. Chapman, 452 U.S. 337, 352 (1981) ("When conditions of confinement amount to cruel and unusual punishment, 'federal courts will discharge their duty to protect constitutional rights.' ") (quoting Procunier v. Martinez, 416 U.S. 396, $405-06$ (1974)); Hutto v. Finney, 437 U.S. $678,685-88$ (1978) (upholding a district court order limiting to 30 days the time a state prisoner may spend in isolation as a remedy for unconstitutional conditions in isolation cells).

4. See, e.g., Rizzo v. Goode, 423 U.S. 362, 378 (1976) (holding that "important 
erman (Pennhurst II) $)^{5}$ may be another example of the Court's efforts to protect state sovereignty from institutional reform hitigation. In that case the district court issued a detailed, affirmative decree restructuring a state program for institutionalized retarded citizens. The Supreme Court held that the eleventh amendment ${ }^{6}$ barred the district court from basing rehef agamst state officials on pendent state claims. ${ }^{7}$ The decision ensures that state courts alone will interpret state law and devise and impleinent corresponding institutional remedies.

Plaintiffs seeking institutional rehef surely bear some of the costs of protecting state sovereignty under Pennhurst II. Depending on financial and strategic considerations, the decision forces them to bring separate suits for their federal and state claims, to forgo their right to a federal forum and bring all claims in state court, or to drop their state claims. This much the Court anticipated. But the opinion may entail an unexpected cost as well. Read hterally, it bars rehef based on any pendent state claim, regardless of the nature of the relief requested. Pennhurst II thus may also prohibit federal courts from issuing negative injunctions based on pendent state claims (sucl as an order enjoining enforceinent of state law), even though such rehef poses virtually no threat to state sovereignty, as traditionally understood under the eleventh ainendment. Althougli the Court has not applied Pennhurst II to a pendent claim for noninstitutional relief, some lower federal courts have read the opinion to prohibit suclı relief. ${ }^{8}$

Part I of this Article analyzes Pennhurst II to determine the scope of its holding. In particular, it explores whether the Court made a doctrinal distinction between clainis for noninstitutional relief and claims seeking institutional reform. It concludes that althougli the Court did not consider carefully the iniportance of pendent jurisdiction, the opinion does

considerations of federalism" weigh against granting affirmative injunctive relief against state agencies).

5. 465 U.S. 89 (1984).

6. The eleventh amendment states:

The Judicial power of the United States shall not be construed to extend to any suit in law or equity, commenced or prosecuted against one of the United States by Citizens of another State, or by Citizens or Subjects of any Foreign State.

U.S. CONST. amend. XI. It was ratified in 1795 in response to the Supreme Court's decision in Chisolm v. Georgia, 2 U.S. (2 Dall.) 419 (1793).

7. As originally conceived, pendent jurisdiction authorized federal courts to decide nonfederal questions necessary to the decision of federal clainis. See Osborn v. Bank of the United States, 22 U.S. (9 Wheat.) 738, 823 (1824). The Court later expanded it to permit federal courts, in certain circunstances, to decide related nonfederal clainis. See, e.g., Siler v. Louisville \& N.R.R., 213 U.S. 175 (1909). See generally 13B C. Wright, A. Miller \& E. CoOper, Federal Practice and Procedure, § 3567-3567.2 (1984 \& Supp. 1986).

8. See, e.g., Frceman v. Michigan Dep't of State, 808 F.2d 1174, 1179-80 (6th Cir. 1987); Baker v. Department of Envtl. Conservation, 634 F. Supp. 1460, 1468 (N.D.N.Y. 1986). 
not foreclose and perhaps even supports a separate eleventh amendment analysis for noninstitutional and institutional reform cases.

Part II argues that the eleventh amendment analysis for pendent claims should turn on the nature of relief. When plaintiffs seek injunctions compromising state sovereignty, such as a structural reform decree based on state law, the courts should invoke the eleventh amendment to deny relief. But when plaintiffs seek only negative injunctions, which normally create relatively little risk to state sovereignty, the Court should permit the district courts to decide pendent state claims. Extending Pennhurst II to sucli cases would unnecessarily undermine federal jurisdiction and threaten important policies-for instance, avoidimg constitutional questions and providing a federal forum for plaintiffs-without significantly reducing federal court intrusion on state autonomy.

\section{PENNHURST}

\section{A. The Eleventh Amendment Before Pennhurst II}

The eleventh amendment is in tension with the fourteenth amendment. Whereas the eleventh amendment bars citizens from sumg states in federal court, the fourteenth amendment bars states from denying individuals due process and equal protection, and authorizes Congress to enforce these prohibitions. Thus, one amendment broadly immunizes the states from suit in federal court, while the other potentially gives the federal courts authority to enforce federal rights agamst state governments. As a result of this tension, the Supreine Court has shaped its doctrimes to accommodate the coinpeting interests underlying these two amendments.

The Court reached sucli an accommodation in Ex parte Young. ${ }^{9}$ In that case the shareholders of a railroad charged that a state law setting maximum shipping rates violated the due process and equal protection provisions of the fourteenth amendment. Pending a final decision, the federal court enjoined the Minnesota attorney general from enforcing the state law. When the attorney general disregarded this order and filed suit in state court to enforce the statute, the federal court lield him in contempt. ${ }^{10}$

In dismissing the attorney general's petition for a writ of habeas

9. 209 U.S. 123 (1908). Ex parte Young was not the first case creating an exception to the eleventh ainendınent for suits against state officers acting in their official capacities, but it is the most fanous, probably because it permits a federal court to enjoin a state judicial proceeding. See Fletcher, $A$ Historical Interpretation of the Eleventh Amendment: $A$ Narrow Construction of an Affirmative Grant of Jurisdiction Rather than a Prohibition Against Jurisdiction, 35 STAN. L. REv. 1033,1041 n.25 \& 1088 n.222 (1983).

10. Young, 209 U.S. at 129-34. 
corpus, the Supreme Court first held the state statute unconstitutional, ${ }^{11}$ and then held that the eleventh amendment did not bar the district court's injunctive order. The Court reasoned that the state officer was "stripped" of his state authority to enforce an unconstitutional statute, and therefore the suit to enjoin the officer was not one "against the state" within the meaning of the eleventh amendment. ${ }^{12}$

The holding in Young enabled the lower federal courts to implement the Court's substantive due process doctrine announced three years earher in Lochner v. New York. ${ }^{13}$ Without the Young exception to the eleventh amendment, plaintiffs could not have challenged state regulatory statutes in federal court; the Court's vision of the fourteenth amendment could have been innplemented only through state courts, subject to Supreme Court review. ${ }^{14}$ Young's innportance, however, transcends the Lochner era. Today the Young exception gives effect to congressional pohicies, contained for exainple in the Civil Rights Act of 1871, of providing a federal forum to adjudicate claims of state violation of federal laws. ${ }^{15}$

Only a year after Young, the Court decided Siler v. Louisville \& Nashville Railroad Co. ${ }^{16}$ In Siler, a railroad company sued in federal court to enjoin enforcement of a state statute regulatimg railroad rates. Instead of reaching the federal constitutional issues, however, the Siler Court decided the case on the basis of a pendent state claim, holding expressly that the court "usually" should avoid constitutional questions. ${ }^{17}$ The Court, it seems, did not view the eleventh amendment as

\section{Id. at 148 .}

12. Id. at 159-60. Ironically, although such a suit is not "against the state" for purposes of the eleventh amendment, the state officer's action is "state action" for purposes of the fourteenth amendment. See Pennhurst II, 465 U.S. at 105.

13. 198 U.S. 45 (1905).

14. See Werhan, Pullman Abstention After Pennhurst: A Comment on Judicial Federalism, 27 WM. \& MARY L. REV. 449, 465 (1986) ("the Young doctrine represents the jurisdictional counterpart to Lochner, opening the courthouse door to active federal control over state economic policy"). Arguably challenges to state regulations could arise in private-party litigation, thus avoiding the need for Young and Lochner. Most cases, however, arise when a regulated party challenges state officials directly.

15. Young does not directly address the congressional policy of providing a federal forum for civil rights plaintiffs, for jurisdiction in that case was based on the "arising under" provision originally enacted in 1875 , see 18 Stat. 470 , now found in 28 U.S.C. $\$ 1331$. See Young, 209 U.S. at 145. The holding in Young, however, did not turn on the basis for jurisdiction, but on the need to accommodate the eleventh and fourteenth amendments.

16. 213 U.S. 175 (1909).

17. See id. at 193 (the policy of avoiding federal constitutional questions "is not departed from without important reasons"). Werhan suggests that Justice Peckham, who wrote Lochner, Young, and Siler, wrote Siler to encourage plaintiffs to bring their claims in federal court. Without Sller, federal courts would have no jurisdiction to hear the pendent state claims, and plaintiffs desiring to avoid two lawsuits would take their federal and state claims to state court. Werhan, supra note 14 , at $465-66$. 
barring the federal courts from hearing pendent state claims. ${ }^{18}$ Recognizing the need to exercise sparingly its powers of constitutional adjudication, the Court, until quite recently, has not departed much from the Siler rule. ${ }^{19}$

When the Court decided Young and Siler, there was some concern that federal courts would displace state courts and assume a continuing supervisory role over the states. ${ }^{20}$ So long as there was a federal claim creating federal jurisdiction, ${ }^{21}$ the federal court had authority to interpret state law and implement its reading of state policy.

To reduce that risk, the Court developed doctrines of restraint designed to reduce the "friction" between the federal and state governments. One important doctrinal restraint has been Pullman abstention. In Railroad Commission v. Pullman Co., ${ }^{22}$ the railroad coinpany sued to enjoin enforceinent of an order of the Texas Railroad Commission treating black and white workers differently. The company argued that the coinimission's order both violated the fourteenth amendment and was unauthorized under state law.

The Court reached neither issue, holding instead that a federal court should abstain from deciding both federal constitutional and pendent state claims involving unsettled issues of state law if state court resolution of the state claims would affect the formulation or disposition of the constitutional question. ${ }^{23}$ By invoking Pullman abstention, a federal court both reduces federal court interference with state sovereignty by giving state courts the first opportumity to pass upon state law, and avoids unuecessary or premature constitutional decisions. ${ }^{24}$ Pullman does not perinit the federal court to evade constitutional questions

18. See infra note 89 .

19. See Hagans v. Lavine, 415 U.S. 528, 546-47 (1974) ("Siler is not an oddity. The Court has characteristically dealt first with possibly dispositive state law claims pendent to federal constitutional claims .... [A]t the very least, [the doctrine] presumes the advisability of deciding first the pendent, nonconstitutional issue.").

20. See, e.g., Ex parte Young, 209 U.S. 123, 175 (1908) (Harlan, J., dissenting) (arguing that Young "would enable the subordinate Federal courts to supervise and control the official action of the States as if they were (dependencies' or provinces"). Congress apparently had similar concerns when it enacted a statute in 1910 requiring injunctions against the enforcenent of state statutes to be issued by a three-judge court. See Act of June 18, 1910, ch. 309, $\S 17,36$ Stat. 539, 557; see also Werhan, supra note 14, at 465 n.64.

21. See Hurn v. Oursler, 289 U.S. 238, 240 (1933) (district court has jurisdiction over pendent claims so long as the federal question is "not plainly unsubstantial").

22. 312 U.S. 496 (1941).

23. Id. at 500-01; see also Hawaii Hous. Auth. v. Midkiff, 467 U.S. 229, 236 (1984); Colorado River Water Conservation Dist. v. United States, 424 U.S. 800, 814 (1976); Harrison v. NAACP, 360 U.S. 167, 176-77 (1959). For a thorough discussion of Pullman abstention, see Field, Abstention in Constitutional Cases: The Scope of the Pullman Abstention Doctrine, 122 U. PA. L. REV. 1071 (1974).

24. See Pullman, 312 U.S. at 501 (abstention allows federal courts to act with " "scrupulous regard for the rightful independence of the state governments" ") (quoting Di Giovanni v. Camden 
entirely (indeed, a state decision providing the plaintiff no relief under state law inay force the federal court to rule on the constitutional issue), but it avoids such questions unless and until they are squarely presented by an authoritative interpretation of state law. ${ }^{25}$

The decision in Pullman completed the doctrinal package for cases challenging the constitutionality of state statutes and regulations. With Young, Siler, and Pullman, the Court was able to accommodate the potentially conflicting policies of providing a federal forum to hear claims of state violations of federal laws, avoiding unnecessary or premature constitutional decisions, and protecting state sovereignty.

\section{B. The Pennhurst Litigation}

The Court's doctrinal balance of these competing policies has become outmoded in the last two decades as a result of a new style of litigation in which plaintiffs seek not to block enforcement of a state law, but to compel the state to provide a certain type, quantity, and quality of services. ${ }^{26}$ In so-called "institutional reform litigation," the plaintiffs look to federal courts to oversee the day-to-day activities of state institutions, or even to create new social service programs. The injunctive decrees, which often specify in minute detail the affirmative obligations of state agencies and institutions, nornally require court-appointed officials to implement thein. In sharp contrast to the "noninstitutional relief" in Young and Siler, institutional reform decrees restrict state autonomy by requiring the state to provide funds for new social programs and by dis-

Ins. Ass'n, 296 U.S. 64, 73 (1935)); Louisiana Power \& Light Co. v. City of Thibodaux, 360 U.S. 25, 28 (1959) (Pullman is a "policy derived from our federalism").

25. A district court invoking Pullman has two options. The conventional practice is to send the parties to state trial court to pursue their state law remedies. Alternatively, the federal court may certify the state law issue to the state supreme court. See 17 C. WRIGHT, A. MiLLER \& E. Cooper, supra note 7, § 4248, at $525 \mathrm{n.29}$; id. at $199 \mathrm{n.29}$ (Supp. 1986) (certification procedures exist in about one-half the states). For a useful discussion of the difference between certification and full abstention, see Field, The Abstention Doctrine Today, 125 U. PA. L. REV. 590, 605-09 (1977).

Following a state court ruling, a plaintiff may return to federal court to adjudicate the remaiuing federal claims, see England v. Louisiana State Bd. of Medical Examiners, 375 U.S. 411 , 415-17 (1964), or for resolution of both federal and state claims if the state court did not decide the state law issues, see Louisiona Power \& Light Co., 360 U.S. at 29. Without such a procedure to ensure resolution of state law issues, federal courts would be reluctant ever to invoke Pullman abstention.

26. See generally Chayes, The Role of the Judge in Public Law Litigation, 89 HARv. L. REV. 1281 (1976); Fiss, The Supreme Court, 1978 Term-Foreword: The Forms of Justice, 93 HARV. L. REV. 1 (1979).

For a general description of institutional reform litigation, see Diver, The Judge as Political Powerbroker: Superintending Structural Change in Public Institutions, 65 VA. L. REV. 43, 49-64 (1979); Fletcher, The Discretionary Constitution: Institutional Remedies and Judicial Legitimacy, 91 YALE L.J. 635, 637-41 (1982); For examples of detailed decrees, see Gewirtz, Remedies and Resistance, 92 YALE L.J. 585, 597 n.26 (1983). 
placing state discretionary authority. ${ }^{27}$

In recent years, the Court has moved to limit the availability of this kind of rehef. ${ }^{28}$ If the Pennhurst litigation exemplifies institutional reform litigation, Pennhurst II demonstrates the Court's resolve to restrict the authority of federal judges to reform state governmental institutions. In holding that relief based on pendent state claims violates the eleventh amendment, Pennhurst II may be one of a series of Supreme Court cases protecting state sovereignty by restricting institutional reform litigation. This view of the decision suggests that the holding im Pennhurst $I I$ is limited to institutional reform cases, leaving federal courts free to issue negative injunctions or provide other noninstitutional rehef based on pendent state claims. Whetlier Pennhurst II applies only to institutional reform litigation is unclear, lowever, for some of the language in the opinion broadly suggests that the eleventh amendment bars all rehef based on pendent state claims.

\section{The Litigation}

In 1974 public interest lawyers filed suit in federal district court in Pennsylvania on behalf of the mentally retarded residents of Pennhurst State School and Hospital. The suit alleged that the 1400 residents $^{29}$

27. Institutional reform decrees and the negative injunctions in Siler and Young are polar extremes in a continuun of prospective relief, and thus are useful paradigms for analyzing the Pennhurst II holding. Throughout this Article I refer more generally to "institutional reform" and "noninstitutional" relief. Most forms of rehef fall comfortably into one of these two categories.

A mandatory injunction requiring an official to perform a nondiscretionary state duty poses a relatively minor threat to state sovereignty, for it normally neither displaces state discretionary authority nor imposes a burden on the state treasury. As a result, I characterize such rehef as "noninstitutional."

Depending on the court's decision, declaratory relief could fall under either category. If the court's order declaring institutional conditions to be illegal was extremely detailed, leaving little doubt what remedial measures would be required, the order would raise many of the same eleventh anendment problems that would arise if the court issued an institutional reform decree. If, on the other hand, the court simply made factual findings describing institutional conditions and declared the ensemble of conditions to be illegal, the threat to state sovereignty would be more attenuated, for the order would not have constrained the state's discretion in remedying the illegality or required expenditure of state funds.

Otlier kinds of affirmative relief are more difficult to categorize. Even though injunctive relief may be sought for a single individual, it nevertheless may be "institutional reform" relief in that the relief necessarily reforms the institution for a much larger class of potential plaintiffs. See, e.g., City of Los Angeles v. Lyons, 461 U.S. 95 (1983) (plaintiff seeking court order to improve police training and keep better records of incidents of police brutality). In other cases the impact of affirmative relief may be more confined. An injunction by one individual for better medical care in an institution does not necessarily require reformation of the agency's practices for all residents. Such relief nevertheless interferes with state discretionary authority and may well require the expenditure of state funds. Moreover, in many cases, it will precipitate institutional reform.

28. See, e.g., Rizzo v. Goode, 423 U.S. 362 (1976) (holding that the intrusiveness of federal injunctive relief is a factor to be taken into account in deciding whether to grant relief); see also infra notes 117-30 and accompanying text.

29. See Burt, Pennhurst: $A$ Parable, in IN THE INTERest of ChILdRen 265, 267 (R. Mnookin 
lived under inhumane conditions, in violation of state and federal laws. Although the plaintiffs' lawyers originally sued to improve conditions in Pennhurst, they soon amended their complaint to seek a court order both to close Pennhurst and to create a network of small community-based facilities providing proper care and habilitation. ${ }^{30}$

Following a lengthy trial, the district court held that conditions in the state institution violated a variety of state and federal statutes and constitutional provisions. ${ }^{31}$ In particular, the court held the conditions in Pennhurst violated a due process right to habilitation, ${ }^{32}$ an eighth and fourteenth amendment right to be free froin harm, ${ }^{33}$ an equal protection riglit not to be segregated in an institution providing inadequate habilitation, ${ }^{34}$ a state statutory right to minimally adequate habilitation,,${ }^{35}$ and a federal statutory right to nondiscriminatory treatment. ${ }^{36}$ The court ordered the state to close Pennhurst and create commumity facilities for Pennhurst's residents, ${ }^{37}$ and appointed a special master to create and implement a detailed deinstitutionalization plan. ${ }^{38}$ Together with its staff, the special master's office comprised a small bureaucracy that would plan the institution's future, momitor the institution's progress, and make inany of the daily decisions normally handled by state officials. ${ }^{39}$

ed. 1985). Before the deinstitutionalization movement began in the late 1960 's, Pennhurst housed nearly 4000 residents. Halderman v. Pennhurst State School \& Hosp., 446 F. Supp. 1295, 1302 (E.D. Pa. 1977). By 1978, when the district court issued its initial decree, the state had reduced that number to under 1200. Halderman v. Pennhurst State School \& Hosp., 542 F. Supp. 619, 624 (E.D. Pa. 1982).

30. For a thorough description of the Pennhurst litigation, see Burt, supra note 29.

31. Halderman v. Pennhurst State School \& Hosp., 446 F. Supp. at 1314-24. The district court found Pennhurst to be an overcrowded, impersonal institution, where violence and injuries among residents were common, the overworked staff relied excessively on physical restraints and psychotropic drugs to control residents' behavior, medical treatment was inadequate, and education and training for residents were virtually nonexistent. Id. at 1302-12.

32. Id. at 1318.

33. Id. at 1321 .

34. Id. at 1322 .

35. Id. at 1323 .

36. Id. at 1324 .

37. Id. at $\mathbf{1 3 2 5 .}$

38. The court appointed the special master to oversee the deinstitutionalization and interim operation of Pennhurst, and later appointed a hearing master to hear individual claims from residents resisting transfer from Pennhurst. Halderman v. Pennhurst State School \& Hosp., 545 F. Supp 410, 411, 415 (E.D. Pa. 1982). The special master alone had a staff of 14, see id. at 419, and at one point a monthly budget of almost $\$ 60,000$. Halderman v. Pennhurst State School \& Hosp., 533 F. Supp. 631, 635 (E.D. Pa. 1981).

39. The special master's plan, adopted by the court, regulated many details of life at Pennhurst. The plan detailed instructions for recognizing and reporting resident abuse; limitations on the use of physical restraints and seclusion; limitations on and procedures for medication and health care (including scheduling of regular medical exams); requirements for wheelchairs; requirements for positioning residents at mealtimes; sanitation regulations; and procedures for reporting and remedying deficiencies-including a chart assigning responsibilities and establishing 
The Third Circuit affirmed the district court's holding on liability and substantially affirmed its order for injunctive rehef. ${ }^{40}$ The court, however, based its judgment on a ground not rehed upon by the district court-the rights it read into the federal Developmentally Disabled Assistance and Bill of Rights Act. ${ }^{41}$

The Supreme Court agreed to hear the case. ${ }^{42}$ In Pennhurst $I{ }^{43}$ the Supreme Court held that there were no implied rights creating a cause of action in the federal statute. Notably, the majority and dissent both strongly suggested that they wanted to limit the scope of institutional relief. ${ }^{44}$ The Court reinanded the case to the Third Circuit for consideration of the other federal and state claims. ${ }^{45}$

On remand, the Third Circuit held that the Pennsylvamia Mental Health and Mental Retardation Act of $1966^{46}$ supported the district court's injunction. ${ }^{47}$ The appellate court specifically held that the eleventh ainendment did not bar rehef based on the pendent state claim..$^{48}$ Relying on the Supreme Court's opinion in Siler, which it viewed as presenting the "identical problem," the Third Circuit reasoned that it should, if possible, avoid constitutional questions and dispose of the case

procedures for reporting each type of violation. For each set of regulations, the special master's liaison was to monitor and conduct independent inspections of the practices and premises. See Order of Apr. 24, 1980, at 10-24, Pennhurst (No. 74-1345) (E.D. Pa.) (estabhishing special master).

40. Halderman v. Pennhurst State School \& Hosp., 612 F.2d 84 (3d Cir. 1979) (en banc).

41. Pub. L. No. 94-103, 89 Stat. 486 (1975), codified at 42 U.S.C. $\S \S 6001-6081$ (1982). The Court of Appeals affirmed habihty on the basis of both the rights it implied in this statute, see Pennhurst, 612 F.2d at 95-100, and the state Mental Health and Mental Retardation Act of 1966, PA. STat. ANN. tit. 50, $\S$ 4101-4704 (Purdon 1969), see Pennhurst, 612 F.2d at 100-03. The court, however, affirmed injunctive rehef only on the basis of the federal statute. See id. at 104-07.

Although the Third Circuit largely affirmed the relief ordered by the district court, it modified the decree in two minor ways. First, the Third Circuit reversed that part of the district court's order requiring the state to provide alternative employment for displaced Pennhurst employees. $I d$. at 113. Second, the court of appeals reversed the order closing Pennhurst entirely, reasoning that Pennhurst may be the best placement available for some individuals. Id. at 113-15. The Third Circuit required the district court to hold, or designate a hearing master to hold, individual placement hearings, using a presumption in favor of deinstitutionalization. Id. at 114-15.

42. Pennhurst State School \& Hosp. v. Halderman, 447 U.S. 904 (1980). During the time between the initial injunction and the first Supreme Court ease, the state sought and was denied stays by both the district court and court of appeals. See, e.g., Halderman v. Pennhurst State School \& Hosp., 451 F. Supp. 233 (E.D. Pa. 1978) (denying a stay pending the initial appeal); 526 F. Supp. 409 (E.D. Pa. 1981) (denying a stay pending decision by Third Circuit following reversal and remand by Suprente Court in Pennhurst I); see also Pennhurst, 612 F.2d 84, 90 (3d Cir. 1979) (stating that the injunction's "implementation has gone forward pending appeal").

43. 451 U.S. 1 (1981).

44. See id. at 54 (White, J., dissenting) ("In any event, however, the court should not have assumed the task of managing Pennhurst or deciding in the first instance which patients should remain and which should be renoved."); id. at 29, 30 n.23 (majority expressly agrecing with dissent on this point).

45. Id. at 31 .

46. PA. Stat. ANN. tit. 50, $\$ \$ 4101-4704$ (Purdon 1969).

47. Halderman v. Pennhurst State School \& Hosp., 673 F.2d 647, 656 (3d Cir. 1982) (en banc).

48. Id. at 659 . 
on a state ground. ${ }^{49}$

The Supreme Court again reviewed the Third Circuit's judgment, this time holding that the eleventh amendinent barred injunctive relief against state officials based on state claims. ${ }^{50}$ Several observers concluded that Pennhurst $I I$ overruled Siler. ${ }^{51}$

\section{Pennhurst II}

Although there is rooin for disagreeinent, the reports of Siler's death may be exaggerated. The Court never declared Siler overruled. ${ }^{52}$ Nor did it evaluate eleventh ainendment doctrine in hight of the coinpeting pohicies underlying pendent jurisdiction. Rather, the opinion appears to be largely the product of the Court's preoccupation with the impact of institutional reforn higation on state sovereignty. Arguably, the holdmg in Pennhurst II may be limited to cases requesting institutional reform.

The Pennhurst II majority began its analysis with the uncontroversial premise that the importance of the eleventh aunendment rests "in its affirmation that the fundamental principle of sovereign immunity limits the grant of judicial authority in Art. III."53 In defining the jurisdictional limitations imposed by sovereign immunity, the Court was "gnided by '[t]he primciples of federalisin that inform the Eleventh

\section{Id. at 658 .}

50. Pennhurst $I I, 465$ U.S. at 124-25.

Despite two Supreme Court reversals, the plaintiffs managed in the end to obtain the relief they wanted. At the behest of attorneys for the Pennsylvania Association for Retarded Citizens (PARC), see Response of PARC et al. to the Court's Inquiry on Mootness, at 3-4, Halderman v. Pennhurst State School \& Hosp. (Nos. 78-1490, 78-1564, 78-1602), the Third Circuit appointed a senior circuit judge "to hold such prehearing conferences as he deems appropriate." Order of Mar. 19, 1984, Pennhurst (Nos. 78-1490, 78-1564, 78-1602). With the judge's guidance, the parties reached a settlement, under which the state agreed to close Pennhurst by July 1986, fund community retardation facilities, create community placements for an additional 200 persons who were not residents of Pennhurst, and pay the planitiff' attorneys about $\$ 1.55$ million in fees. See Memorandum \& Order of Apr. 5, 1985, at 11, Pennhurst (No. 74-1345) (approving final settlement); Order of July 23, 1984, Pennhurst (Nos. 78-1490, 78-1574, 78-1602) (approving attorneys' fees settlement agreement).

51. See, e.g., Pennhurst II, 465 U.S. at 166 n.52 (Stevens, J., dissenting); Shapiro, Wrong Turns: The Eleventh Amendment and the Penuhurst Case, 98 Hanv. L. Rev. 61,65 n.29 (1984); Werhan, supra note 14 , at 484.

52. Under the Court's reasoning, however, Pennhurst II did not present the question whether Siler should be overruled. According to the Pennhurst II majority, the Court had never held "direetly" that the eleventh anendment permitted a federal court to deeide pendent state claims. The question being an "open one," 465 U.S. at 119, there was nothing to overrule. See infra text accompanying notes $87-89$.

53. 465 U.S. at 98; see also id. at 141-42 (Stevens, J., dissenting) ("under our cases it is the doctrine of sovereign immunity, rather than the text of the Amendment itself, which is critical to the analysis of any Eleventh Amendment problem"). While the dissenters agreed that the doctrine of sovereign immunity underlay the eleventh amendment, they took a narrower view than did the majority of its scope. Id. at $140-59$. 
Amendment doctrine." "54 From these principles, the Court derived the general rule that the eleventh amendment bars federal suits against the states and their agencies ${ }^{55}$ and bars suits against state officers "if the decree would operate against" the state. ${ }^{56}$

The Court accepted Ex parte Young 57 as an "important exception" to this general rule. ${ }^{58}$ Nevertheless, the Pennhurst II Court termed the authority-stripping rationale in Young a "fiction"59 necessary "to permit the federal courts to vindicate federal rights and hold state officials responsible to 'the supreme authority of the United States." "60 Because the Pennhurst II Court viewed Young as specially designed to protect federal rights, it held the exception "inapplicable"61 when the judgment under review rested on state law. According to the Court, a federal decree based on state law poses a greater threat to federalism, not only because it fails to vindicate the supremacy of federal law (which would have been a compensatimg benefit to the mjury to state sovereignty), but also because the "intrusion on state sovereignty [is greatest] when a federal court imstructs state officials on how to conform their conduct to state law."62 The desire to protect state autonomy, and thus give meaning to the eleventh amendment, led the Pennhurst II Court to confine the Ex parte Young exception to claims involving federal rights.

Having defined the basic eleventh amendment doctrime as it apphies to pendent state claims, the Court considered two possible exceptionsthe ultra vires doctrime and the doctrine of pendent jurisdiction. In the

54. Id. at 100 (quoting Hutto v. Finney, 437 U.S. 678,691 (1978)).

55. Id. One application of this rule is that the state may not be named as a defendant. Id; see also Alabama v. Pugh, 438 U.S. 781 (1978) (barring suit against the State of Alabama and its Board of Corrections by inmates alleging unconstitutional prison conditions). The eleventh amendment, however, does not bar suits agamst counties and other substate units of government. See, e.g., Lincoln County. v. Luming, 133 U.S. 529, 530 (1890) (county); Mt. Healthy City School Dist. v. Doyle, 429 U.S. 274, 280 (1977) (school board).

56. Pennhurst II, 465 U.S. at 101 (quoting Hawaii v. Gordon, 373 U.S. 57, 58 (1963)); see also id. at $101 \mathrm{n} .11$ ("The general rule is that a suit is against the sovereign if 'the judgment sought would expend itself on the public treasury or domain, or interfere with the public administration,' or if the effect of the judginent would be 'to restrain the Government from acting, or to compel it to act.' ") (quoting Dugant v. Rank, 372 U.S. 609, 620 (1963)).

57. 209 U.S. 123 (1908).

58. Pennhurst IJ, 465 U.S. at 102 . Two other, and in this case irrelevant, exceptions are when the state consents to suit in federal court, see Edelman v. Jordan, 415 U.S. 651 (1974) (constructive consent), and when Congress, exercising its fourteenth amendment enforcement powers, abrogates eleventh amendment protections, Fitzpatrick v. Bitzer, 427 U.S. 445 (1976). The Court has held that 42 U.S.C. $\S 1983$ is not a congressional abrogation of eleventh amendment immuuity. Quern v. Jordan, 440 U.S. 332, 342 (1979).

59. 465 U.S. at 105.

60. Id. (quoting Young, 209 U.S. at 160).

61. Id. at 106.

62. Id. 
end, the Court concluded that neither doctrine was weighty enough to overcome the jurisdictional limitation in the eleventh amendment.

\section{a. Ultra Vires Doctrine}

The Court's discussion of the ultra vires doctrine was in response to the principal dissenting opinion. Relying on language in both Larson $v$. Domestic \& Foreign Commerce Corp ${ }^{63}$ and the plurality opinion in Florida Department of State v. Treasure Salvors, Inc., ${ }^{64}$ the dissent argued that the state officials responsible for Pennhurst had acted ultra vires their state authority, and thus outside the shield of sovereigu immunity. ${ }^{65}$

The ultra vires exception to sovereign immunity found modern expression in Larson. Larson was a suit to force a federal official to comply with the terms of a contract between the federal government and the plaintiff. The issue before the Court was whether the suit was against the federal government. In the course of holding that the suit was against the government, and thus that sovereign immunity barred the suit, the Court wrote: "Where the officer's powers are himited by statute, his actions beyond those limitations are considered individual and not sovereign actions. ... [Thus his] actions are ultra vires his authority and therefore may be made the object of specific relief."

Treasure Salvors arose from a challenge to a district court order requiring federal authorities to seize historical artifacts that Florida held under a claim of ownership. A plurality of the Court rehed on language in Larson to write that the eleventh amendment is no bar if the state officer "acted beyond the scope of his statutory authority."67 As the plurality determined that Florida had no "colorable clain" to the property under state law, ${ }^{68}$ state officials were acting ultra vires in retaining the property ${ }^{69}$ and thus were subject to suit in federal court.

When they became the dissenters in Pennhurst II, the Treasure Salvors plurality argued that Larson and Treasure Salvors stood for the proposition that state officials violating state law were not protected by sovereign immunity. Because the officials violated state law, they were acting beyond their statutory authority. Since "[n]o sovereign would authorize its officials to violate its own law,"70 such officials were

63. 337 U.S. 682 (1949).

64. 458 U.S. 670 (1982). The author of the plurality opinion in Treasure Salvors, Justice Stevens, was the author of the principal dissent in Pennhurst II. The dissenters in Treasure Salvors became the majority in Pennhurst II when the Chief Justice joined them.

65. Pennhurst II, 465 U.S. at 153-59 (Stevens, J., dissenting).

66. Larson, 337 U.S. at 689.

67. Treasure Salvors, 458 U.S. at 689.

68. Id. at 694.

69. Id. at 697.

70. Pennhurst II, 465 U.S. at 155 (Stevens, J., dissenting); see also id. at 138 (Stevens, J., 
"stripped of [their] official or representative character"71 as much as if they had violated the Constitution. In short, "the immunity determination depends upon the merits of the plaintiff's claim."72 Although the dissenters indicated in passing that they would maintain an eleventh amendinent distinction between damages to be paid from the state treasury and injunctive rehef, ${ }^{73}$ the language in the opinion strongly suggested they would sharply restrict the constitutional doctrine of state sovereign immunity in the federal courts. ${ }^{74}$

The majority in Pennhurst II rejected the dissent's ultra vires argument in a thoughtful discussion of their primary concern-ensuring a substantial role for state sovereign immunity. Although the Court found language in both Larson and Treasure Salvors suggesting that the ultra vires doctrine applies only when an official acts utterly without delegated authority, ${ }^{75}$ a standard that would bar suit in this case, ${ }^{76}$ it rejected the dissent's ultra vires argument more as a inatter of judgment than of deductive logic.

Conceding that the dissent's "authority stripping" theory was a logical extension of Young, ${ }^{77}$ the Court reasoned that the logic was virtually without limits and would obliterate the eleventh anndment. ${ }^{78}$ The majority beheved that under the dissent's theory, the eleventh amendment would protect the state only where the plaintiffs failed to find a state statute that the defendants conld be charged with violating, or in the rare case where the plaimtiffs "foohshly" named the state itself as a

dissenting) ("it is only common sense to conclude that States do not authorize their officers to violate their legal duties"). This language is reminiscent of Young, where the Conrt wrote that "the use of the name of the State to enforce an unconstitutional act . . . is a proceeding without the authority of . . . the State in its sovereign or governmental capacity." Ex parte Young, 209 U.S. 123, 159 (1908).

71. Pennhurst II, 465 U.S. at 147 (Stevens, J., dissenting) (quoting Young, 209 U.S. at 160).

72. Id. at 154 (Stevens, J., dissenting). The dissenters in Treasure Salvors had predicted this arguinent. See Treasure Salvors, 458 U.S. at 703.

73. See Pennhurst II, 465 U.S. at 146 n.29 (Stevens, J., dissenting).

74. The Pennhurst II dissenters later joined Justice Brennan's dissent in Atascadero State Hosp. v. Scanlon, 473 U.S. 234 (1985). In a previous case, Justice Brennan had argued that the eleventh amendment did not apply to suits by the state's citizens. See Einployees v. Department of Pub. Health \& Welfare, 411 U.S. 279, 315-22 (1973) (Brennan, J., dissenting). In Atascadero, however, he adopted a different theory. Implicitly rejecting the dissent's opinion in Pennhurst II (which he had signed), he argned that there is "no constitutional principle of state sovereign immunity, and no constitutionally unandated policy of excluding suits against States from federal court." Atascadero, 473 U.S. at 259.

75. See Pennhurst II, 465 U.S. at 101 n.11 (quoting Treasure Salvors, 458 U.S. at 697) (suit can be brought only when the officer "acts without any authority whatever"); id. at $101 \mathrm{n} .11$ (quoting Larson, 337 U.S. at 690) (The ultra vires theory rests on a "lack of delegated power. A claim of error in the exercise of that power is therefore not sufficient.").

76. Since the petitioners had "broad discretion" under state statutes to provide services for Pennhurst's residents, their actions were not ultra vires. Pennhurst II, 465 U.S. at 101 n.11.

77. Id. at 114 n.25.

78. Id. (argning that the dissent's view of the ultra vires doctrine "would virtually eliminate the constitutional doctrine of sovereign intnunity"). 
defendant..$^{79}$ As such, the eleventh amendment would be "a pretense," for it would mean that this suit was not "agamst the state" even though the district court's order required the state both to close Pennhurst and to build and operate community facilities according to detailed instructions. ${ }^{80}$

The Court concluded that even though it might be "difficult to draw principled lines short of" the dissent's result, ${ }^{81}$ some line must be drawn to preserve the substance of the eleventh amendment. Recalling that the Larson Court "wisely recoiled"82 from holding that an official's tort is necessarily ultra vires his authority, ${ }^{83}$ thus preserving the doctrine of sovereign immunity for the federal government, the Pennhurst II Court similarly limited the ultra vires doctrine to keep the eleventh amendment vital. $^{84}$

\section{b. Pendent Jurisdiction Doctrine}

The dissent also argued that the Court's opinion was unwise in that it overruled long established precedent, beginning with Siler v. Louisville \& Nashville Railroad Co., ${ }^{85}$ authorizing federal courts to decide pendent state claims. ${ }^{86}$ Unfortunately, the Court did not address the pendent jurisdiction argument as carefully as it handled the shippery ultra vires issue. On the contrary, the Court mampulated labels without much sensitivity for the underlying issues.

The Court readily accepted the general proposition that a "federal court may resolve a case solely on the basis of a pendent state-law claim, and that, im fact, the court usually should do so in order to avoid federal constitutional questions." ${ }^{87}$ But the Court concluded, in a curiously

79. Id. at 116; see also Currie, Sovereign Immunity and Suits Against Government Officers, 1984 SuP. CT. REV. 149, 151 \& n.11 (pointing out that sovereign immunity, under the eleventh amendment, must bar more than just suits where the state is a named defendant: "People are not likely to amend constitutions just to change captions on complaints.").

80. Pennhurst II, 465 U.S. at 107.

81. Id. at $114 \mathrm{n} .25$.

82. Id.

83. See Larson, 337 U.S. at 694.

84. Although the ultra vires exception to the eleventh amendment is not a dead letter, the Court strongly hinted it was prepared to abandon the exception.

[I]t may well be wondered what principled basis there is to the ultra vires doctrine as it is set forth in Larson and Florida Dep't of State v. Treasure Salvors. . . . For present purposes, however, we do no more than question the continued vitality of the ultra vires doctrine in the Eleventh Amendment context. We hold only that to the extent the doctrine is consistent with the analysis of this opinion, it is a very narrow exception . . . .

Pennhurst II, 465 U.S. at 114 n.25; see also id. at 116 (calling the ultra vires doctrine a "narrow and questionable" exception).

85. 213 U.S. 175 (1909).

86. Pennhurst II, 465 U.S. at 159-63 \& 166 n.52; see also Brief of Respondents PARC et al. at 6-12, Pennhurst II (No. 81-2101).

87. Pennhurst II, 465 U.S. at 117 (citation omitted). For the classic descriptions of the reasons 
strained analysis, that neither this general policy nor the Court's past decisions "addressed wliether [pendent jurisdiction] has a different scope when applied to suits against the State," ${ }^{\text {" }}$ and that therefore tlie question was "an open one." 89

Having found tle issue open, the Court summarily resolved it. First, the Court listed the long-accepted justifications for pendent jurisdiction: ${ }^{90}$ promoting "judicial economy, convenience and fairness to hitigants"; 91 allowing courts to avoid unnecessary constitutional decisions; ${ }^{92}$ and making a federal forum available for federal claims. ${ }^{93}$ Then, with virtually no analysis, it dismissed these justifications as mere "considerations of policy"94 trumped by the eleventli amendment. ${ }^{95}$

The Court's logic has a surface plausibility. To the extent the principle of state immunity in federal court derives directly from a constitutional provision, and tlie autliority for pendent jurisdiction is only inferred from general language in the Constitution, the specific restriction on jurisdiction in tlie eleventli amendment sliould prevail when the two conflict. On close examination, however, this logic is unconvincing. The Court's dicliotoiny- "judge-nuade doctrine"96 on the one hand and the "explicit limitation" in the eleventli amendment ${ }^{97}$ on the other-fails

for avoiding unnecessary decision of constitutional questions, sec both Justice Brandeis's concurring opiunon in Ashwander v. Tennessee Valley Auth, 297 U.S. 288, 346-48 (1936) and the Court's opinion in Rescue Army v. Municipal Court, 331 U.S. 549, 571 (1947).

88. Pennhurst $I I, 465$ U.S. at 118.

89. Id. at 119. It is difficult to take seriously the Court's assertion that the question was open. In Greene v. Lousiville \& Interurban R.R., 244 U.S. 499, 506-08 (1917), the Court reaffirmed both Ex parte Young, 209 U.S. 123 (1908) (holding that a suit challenging state enforcement of an allegedly unconstitutional statute is not "against the state" under the eleventh amendment) and Siler v. Louisville \& N.R.R., 213 U.S. 175 (1909) (holding the federal court should decide the case on state grounds). Although the Greene Court did not expressly consider whether the eleventh anendinent barred the pendent claim, it is apparent that the Court did not see the eleventh amendinent as an obstacle to pendent jurisdiction. Indeed, the Pennhurst II majority conceded that Greene "implicitly" viewed the eleventh amendinent as no bar. 465 U.S. at 121.

90. Pennhurst II, 465 U.S. at 121-22.

91. See, e.g., United Mine Workers of Am. v. Gibbs, 383 U.S. 715, 726 (1966).

92. See, e.g., Siler, 213 U.S. at 193.

93. See Ex parte Yonng, 209 U.S. 123 (1908). If the plaintiffs inay not bring their state claims in federal court, they may choose, or be forced because of limited litigation resources, to bring all claims, state and federal, in state court. To the extent Pennhurst $I I$ has this effect, it will undercut Young's policy of inaking available a federal forum to vindicate the supreinacy of federal law. See Pennhurst II, 465 U.S. at 121-22.

94. Pennhurst $I I, 465$ U.S. at 123.

95. The Court did not suggest that pendent jurisdiction doctrine was without foundation. Rather, the Court described it as a doctrine "inferred from the general language of Art. III," id. at 117 , and therefore subordinate to the "explicit limitation on federal jurisdiction contained in the Eleventh Amendment," id. at 118; see also Gibbs, 383 U.S. at 725 (describing the constitutional basis for pendent jurisdiction).

96. Pennhurst $I I, 465$ U.S. at 120.

97. Id. at 118 . 
to persuade, both because the labels are misleading and because the opinion does not address the meaning behind the labels.

Iromically, the reasoning of Pennhurst $I I$ itself undermines the distinction between "judge-made doctrine" and "exphicit constitutional limitation." Not only does the Court acknowledge that eleventh amendment doctrine is derived from "principles" of sovereign immunity and federalism, ${ }^{98}$ and thus is largely judge-made, it spends much of the opimion detailing the judicial development of eleventh amendment doctrine in hight of various "pohicies." Indeed, given the vagne contours of sovereign immunity and federalism principles, eleventh ainendinent doctrine could not be other than judge-made. ${ }^{99}$

More generally, the nature of a constitution requires "that only its great outlines should be marked, its important objects designated, and the minor ingredients which compose those objects, be deduced from the nature of the objects themselves." 100 Necessarily, and quite properly, the Court must look to the purposes or pohcies underlying these "great outlines" in order to define the scope, applicability, and interplay of the Constitution's various provisions.

There are numerous examples of constitutional doctrines that have been shaped by other constitutional provisions, or even concerns outside the Constitution. For instance, the scope of the free speech clause is himited by the "time, place and manner" doctrine, reflecting not a countervailing constitutional right, but rather the legitimate concerns of governance. ${ }^{101}$ Similarly, the eleventh amendment is limited by Ex parte Young, which advances the pohicy, derived from the fourteenth amendment, of making the federal courts available to redress state violations of federal rights. As with the "tinne, place and manner" and Ex parte Young limitations to constitutional provisions, pendent jurisdiction is a judge-made doctrine. Although it was not created to limit the eleventh amendment, the extent, if any, to which tlie doctrine should shape eleventli amendment doctrine turns in part on the reasons judges made it. Tlius, in deciding whether the eleventh amendment bars a federal court from granting relief on a pendent state claim, the Court must weigh the particular need for pendent jurisdiction against the intrusion on state sovereignty.

\section{Id. at 98,100 .}

99. See Brown, Beyond Pennhurst-Protective Jurisdiction, the Eleventh Amendment, and the Power of Congress to Enlarge Federal Jurisdiction in Response to the Burger Court, 71 VA. L. REV. 343,359 (1985) (detailing the various ways in which eleventh amendment doctrine is "judge-made").

100. McCulloch v. Maryland, 17 U.S. 159, 200, 4 Wheat. 316, 407 (1819).

101. See, e.g., City of Renton v. Playtime Theatres, Inc., 106 S. Ct. 925, 928-30 (1986); Grayned v. City of Rockford, 408 U.S. 104, 115-16 (1972). 


\section{c. The Scope of the Pennhurst II Holding}

It is unclear whether the Court intended to hold that the eleventh amendment bars prospective rehef for all pendent state claims when a state official is a defendant, ${ }^{102}$ or whether the Court intended to make a distinction between institutional reform suits and suits seeking noninstitutional rehef. ${ }^{103}$ On the one hand, the opinion does not explicitly limit the holding to certain types of pendent state claims. Indeed, there is some language suggesting that the source of the claim-state law-was the determinative factor in the Court's eleventh amendment analysis. ${ }^{104}$ Nevertheless, the focus of the entire opinion, as well as some of the language, suggests that the Court's new eleventh amendment doctrine will apply only to institutional reform cases such as Pennhurst.

To determine the intended scope of Pennhurst II, one should begin with the Court's statement that "considerations of policy [supporting pendent jurisdiction] cannot override the constitutional limitation on the authority of the federal judiciary to adjudicate suits against a State."105 The critical determination, then, is deciding what factors make a suit one "against a state." More precisely, the issue is whether, under Pennhurst II, the Court will characterize every suit enjoining state officials on the basis of state law as one against the state, and therefore barred by the eleventh amendinent.

There are several mdications in Pennhurst II that the Court's conclusion - that the suit was against the state-turned at least as much on the nature of the rehief as it did on the source of the claim. These indications are found in what the opimion includes, in what it leaves out, and in the doctrinal context of the opinion. First, the Court in several places emphasizes that the nature of the rehef in this case-a structural reform decree-intrudes on state sovereiguty. Second, the Court completely ignores Pullman abstention, which would permit the district court to send unsettled state law questions to state court. By leaving the district courts no opportunity to formulate a remedy, even when state law is

102. Because the Court has held that the eleventh amendment bars all retroactive relief against states, see Edelman v. Jordan, 415 U.S. 651 (1974), the only concern here is whether, under Pennhurst $I I$, the eleventh amendment bars all prospective relief based on state law.

103. See Shapiro, supra note 51, at 83 (suggesting that the Court may have intended such a distinction).

104. Pennhurst II, 465 U.S. at 121 ("We concluded above that a claim that state officials violated state law in carrying out their official responsibilities is a claim against the State that is protected by the Eleventh Amendment."); id. at 106 ("[I]t is difficult to think of a greater intrusion in state sovereignty than when a federal court instructs state officials on how to conform their conduct to state law."); id. (Ex parte Young exception "inapplicable" to state law claims); $c f$. Currie, supra note 79, at 166 n.98 (suggesting that the Court's holding that Young was "inapplicable" to a suit based on state law "[i]n context, ... may only mean that the analysis is different in respect to state-law claims, not that the bar [to relief] is absolute").

105. 465 U.S. at 123. 
unambiguous, the Court indicated that its principal focus is the threat to sovereignty created when a federal court formulates injunctive relief, not simply when it interprets state law. Third, in the last fifteen years the Court has decided a number of cases restricting the availability of institutional reform rehef because of its impact on state sovereignty. In context, Pennhurst II may be seen as a variation on this theme.

A clear indication of the Court's focus on the nature of the relief is in the language used in the opinion. In its discussion of pendent jurisdiction, the Court wrote that "a federal suit against state officials on the basis of state law contravenes the eleventh amendment when-as herethe rehef sought and ordered lias an impact directly on the State itself." 106 The second half of this sentence would be entirely unnecessary if the source of the claim alone-state law-made the suit one against the state. By adding this clause, the Court sigualed that soinething about the relief in Pennhurst has a "direct impact," resulting in an eleventh anendment violation. The Court evidently is referring to the institutional reform remedy, the impact of which may be exacerbated because it is based on state law.

Similarly, in discussing the ultra vires doctrine, the Court wrote that "the relief ordered so plainly ran agamst the State. No one questions that ... the judgments under review commanded action that could be taken ... only if the State provided the necessary funding." 107 The Court then noted that virtually no prior decisions allowed injunctive relief "against State officials for failing to carry out their duties under State statutes." 108

A second, more indirect indication that Pennhurst II turned as much on the nature as on the source of relief is the Court's failure to invoke Pullman abstention. ${ }^{109}$ If the Court liad been concerned primarily about the federalisin probleins that arise when a federal court interprets state law, it could have required the district court to abstain under Pullman, sending the state law issue to state court.

The Court's decision to iguore Pullman ${ }^{110}$ did not stein from its belief that state law was clear and therefore that abstention was unavailable. On the contrary, the Court believed that the proper scope of state

106. Id. at 117 .

107. Id. at $109 \mathrm{n} .17$.

108. Id. at 109 (footnote omitted). The Court noted that the only previous case that arguably allowed affirmative relief against state officials was Rolston v. Missouri Fund Comm'rs, 120 U.S. 390 (1887), in which 'state officials were ordered to comply with 'a plain ministerial duty,' . . a far cry from" the district court's decree in Pennhurst. Pennhurst II, 465 U.S. at 109 n. 18 (quoting Great N. Life Ins. Co. v. Read, 322 U.S. 47, 51 (1944)). In drawing this distinction the Court implied that the affirmative nature of the decree was important to its eleventh amendment analysis.

109. See supra text accompanying notes 22-25.

110. The Court made only a passing reference to the case. See Pennhurst II, 465 U.S. at 122 (referring obliquely to "abstention doctrine"). For a discussion of the effect of Pennhurst II on the Pullman doctrine, see Werhan, supra note 14. 
rights and remedies was unsettled. ${ }^{11}$ More probably, the Court concluded that Pullman abstention would not adequately shield the state against federal intrusion in Pennhurst.

The Court was troubled by the Pennhurst decree because of the mevitable "intrusion on state sovereignty ... . when a federal court instructs state officials on how to conform their conduct to state law." 112 Although the state court may readily provide a basic interpretation of state law (in many cases, there may be little dispute over the general formulation of state-created rights), there remains a liuge gap between articulation and implementation of state law.

Certifying the state issue for a state court interpretation of state law would not afford much protection for state sovereignty because tlie greater injury to state sovereignty occurs in the federal court's implementation, rather than interpretation, of state law. A state court declaration of state-created rights would not fix the proper remedy, for rarely, if ever, is there a smgle acceptable remedy in institutional reform cases. ${ }^{13}$ Rather, the federal court, armed with only the general standard provided by the state court, inay implement its chosen remedy by using federal officials to inake inany or inost of the decisions in planning and operating a state program or facility. ${ }^{114}$

The Court also may feel that it cannot rely on full abstention (sending the state claims to state court for botli a decision on hability and, if necessary, formulation of the corresponding remedy) to protect state autonoiny. Under Pullman, federal judges sliould be reluctant to post-

111. See Pennhurst II, 465 U.S. at 122 n.32.

112. Id. at 106 (emphasis added).

113. The Pennhurst case illustrates this point. During the course of the Pennhurst hitigation, the Pennsylvania Supreme Court decided In re Schmidt, 494 Pa. 86, 429 A.2d 631 (1981), which was a dispute between a county and the state over responsibility for care and treatment of a mentally retarded individual. In its opinion, the state court noted that Pennsylvania law required government agencies to adopt a policy of "normalization," meaning that "the mentally retarded person ... shall have the right to live a life as close as possible to that which is typical for the general population. Consistent with this concept is the requirement that the least restriction consistent with adequate treatment and required care sliall be employed." Id. at 96, 429 A.2d at 636. The Third Circuit cited this opinion to support its interpretation of state law as providing enforceable, substantive rights. Halderman v. Pennhurst State School \& Hosp., 673 F.2d at 651-56. Assuming the federal court correctly interpreted state law, it is apparent that tle federal court could implement the state court's broad requirement in a variety of ways.

114. See Fletcher, supra note 26 , at $644-49,660-63$ (pointing out that district court judges have immense discretion in formulating institutional reform decrees, and arguing that it is not practicable for legislatures or appellate courts to control or guide that discretion); cf. Fallon, Of Justiciability, Remedies, and Public Law Litigation: Notes on the Jurisprudence of Lyons, 59 N.Y.U. L. REV. 1, 45 (1984) (arguing that appellate courts should develop "enforceable remedial principles," but recognizing the "task may be formidable"); Chayes, The Supreme Court 1981 Term-Foreword: Public Law Litigation and the Burger Court, 96 HARv. L. REv. 4, 47 (1982) (arguing that as judges decide more institutional reform cases, the "forms of relief . . . will begin increasingly to converge"). 
pone exercising federal jurisdiction in favor of state court adjudication, ${ }^{115}$ particularly if state law is clear. Moreover, on a human level, district court judges, faced with deplorable institutional conditions, may find it difficult to be sufficiently sensitive to abstract federalism issues and relinquish their reinedial power. ${ }^{116}$ Their natural inclination to address the pressing social probleins before thein may be reinforced by a sense that state courts are overly sensitive to the state's interests. To put it bluntly, district court judges cannot be trusted to abstain in favor of state courts. By depriving federal judges of the discretion to formulate institutional reform decrees based on state law, the Pennhurst II holding ensures that state courts will both construe state law and devise appropriate reinedies.

The third indication that Pennhurst II is directed largely at institutional reform relief, and not simply at the source of the claim, inay be deduced froin other cases revealing the Court's unease with (or perhaps hostility towards) institutional relief. These cases indicate that Pennhurst $I I$ is einbleinatic of the Court's evolving concern with the impact of institutional reform decrees on state autonouny.

Since 1971 the Court has restricted the availability of institutional reform decrees against state and local officials. Beginning with Younger v. Harris, ${ }^{117}$ the Court has held, despite Ex parte Young, ${ }^{118}$ that principles of federalism are important factors in deciding whether to grant prospective rehef that would disrupt the operation of state courts ${ }^{119}$ and local agencies. ${ }^{120}$ In Younger, for example, the Court held that a federal court inay not enjoin a pending state criminal trial, ${ }^{121}$ in Rizzo v. Goode, ${ }^{122}$ the

115. See Colorado River Water Conservation Dist. v. United States, 424 U.S. 800, 813 (1976) (abstention "is the exception, not the rule").

116. See Bell v. Wolfish, 441 U.S. 520, 562 (1979) ("Judges, after all, are human. They, no less than others in our society, have a natural tendency to believe that their individual solutions to often intractable problems are better ....").

117. 401 U.S. 37 (1971).

118. 209 U.S. 123 (1908).

119. See, e.g., O'Shea v. Littleton, 414 U.S. 488,500 (1974) (denying injunctive relief against state court officials for alleged discrimination in sentencing and setting bail because such relief would involve "an ongoing federal audit of state criminal proceedings"); Younger v. Harris, 401 U.S. 37, 41 (1971) (absent extraordinary circunistances, a federal court nuay not declare unconstitutional, or enjoin enforcentent of, a state criminal statute if a state criminal proceeding is pending).

120. See, e.g., City of Los Angeles v. Lyons, 461 U.S. 95, 112 (1983) (denying injunctive relief prohibiting police use of chokeholds and requiring the police department to improve its training program and keep regular records of chokehold incidents); Rizzo v. Goode, 423 U.S. 362, 380 (1976) (denying injunctive relief requiring city officials to institute a program for handling citizen complaints against police). See generally Mishkin, Federal Courts as State Reformers, 35 WASH. \& LEE L. REv. 949 (1978) (arguing for restraint in issuing institutional relief); Fallon, supra note 114 (criticizing the Court's decision in Lyons as improperly restricting the availability of injunctive relief).

121. The Court has expanded Younger to prevent federal courts from interfering with a variety of pending state proceedings. See, e.g., Pennzoil Co. v. Texaco Inc., 107 S. Ct. 1519 (1987); Ohio Civil Rights Comm'n v. Dayton Christian Schools, 106 S. Ct. 2718 (1986) (administrative hearing in a civil rights enforcement case); Middlesex County Ethics Conun. v. Garden State Bar Ass'n, 457 
Court held that the district court improperly ordered city officials to create a program for handling citizens' complaints as a means of reducing the number of incidents of police brutality. These cases einphasize that "the need for a proper balance between state and federal authority counsels restraint in the issuance of injunctions against state officers engaged in the admimistration of the States' criminal laws." 123 While some of these cases involved local officials, and thus did not raise an eleventh amendinent issue, they all involved the federalism concerns underlying Pennhurst II.

Even when the Court has not invoked principles of federalism to bar injunctive relief, it has signaled its doubts concerning the ready availability of institutional reform decrees. For example, in Bell v. Wolfish, ${ }^{124}$ which rejected a due process challenge to the practice of housing two federal pretrial detainees in a cell designed for one, the Court warned judges not to become "enmeshed in the minutiae of prison operations." ${ }^{125}$ In Rhodes v. Chapman, ${ }^{126}$ rejecting an eighth amendment challenge on similar facts, the Court admorrished judges not to assume that state officials "are insensitive to the requirements of the Constitution."127 Echoing the language in these opmions, both the inajority and dissent in Pennhurst $I$ agreed that the district court "should not have assumed the task of inanaging Pennhurst."128

The logic of and motivation underlying these cases is hardly limited to suits seeking federal oversight of some aspect of the state criminal justice system. Rather, these cases suggest that a district court should be reluctant to grant remedial relief against state or local institutions when that rehef would threaten state sovereignty, whether by impinging on the state fisc ${ }^{129}$ or on other aspects of state discretionary authority. ${ }^{130}$

U.S. 423 (1982) (bar disciplinary proceedings); Huffman v. Pursue, Ltd., 420 U.S. 592 (1975) (public nuisance suit to close a novie theater).

122. 423 U.S. 362 (1976).

123. Lyons, 461 U.S. at 112.

124. 441 U.S. 520 (1979).

125. Id. at 562 .

126. 452 U.S. 337 (1981).

127. Id. at 352 .

128. Pennhurst State School \& Hosp. v. Halderman, 451 U.S. 1, 54 (1981) (White, J., dissenting); id. at 29, 30 n.23; see also Youngberg v. Romeo, 457 U.S. 307, 322 (1982) (in determining whether an institutionalized retarded person has been afforded his constitutional right to minimally adequate training, a court should defer to the judgment exercised by qualified professionals in order to minimize federal court interference with the internal operations of the institutions).

129. In Fair Assessment in Real Estate Ass'n v. McNary, 454 U.S. 100 (1981), the Court relied on Younger to hold that principles of comity and federalism barred a federal damages suit alleging unequal property taxation in violation of due process and equal protection.

130. See M. Redish, Federal Jurisdiction: Tensions in the Allocation of Judicial POWER 319 (1980) (both Rizzo and Younger refiect the "desire to avoid federal judicial interference with the discretionary operation of state and local executive agents"); $i d$. at 321 (arguing that Rizzo 
The injunctive rehef in Pennhurst undercut the state's autonomy by imposing specific, affirmative obligations, nullifymg the discretionary authority of state officials to define and implement state law, ${ }^{131}$ and effectively requiring the state legislature to allocate funds for state priorities as determined by a federal judge. ${ }^{132}$ State officials were subordinated to a federal judicial bureaucracy, and the state fisc was put at the disposal of federal officials. The Pennhurst decree-througli which the district court reorganized a state program for severely retarded citizens-involved the sort of interference with autonomy with wlich a doctrine of sovereign immunity ought to be concerned. ${ }^{133}$

Given the nature of tle rehef in Pennhurst, it is no surprise that the Pennhurst II Court quoted Rizzo in questioning the appropriate scope of institutional rehef even if based on federal law. ${ }^{134}$ Pennhurst II follows the Younger line of cases in protecting the discretionary authority of state officials from federal oversight while inaintaining the core importance of Ex parte Young.

was directed especially at "administrative" injunctions, that is, injunctions requiring the court to assume "supervisory responsibility for overseeing the ongoing operation of an executive agency"); Fiss, Dombrowski, 86 YALE L.J. 1103, 1154 (1977) (Rizzo was a "clear signal" that "federal access for administrative injunctions aimed at any state officials was to be curtailed").

131. See Pennhurst II, 465 U.S. at $111 \mathrm{n} .20$ ("discretionary duties have a greater impact on the sovereign because they "brin[g] the operation of governmental machinery into play' ") (quoting Justice Frankfurter's dissent in Larson v. Domestic \& Foreign Commerce Corp., 337 U.S. 682, 715 (1949)); id. at 113-14 (stating that limitations on the ultra vires doctrine in Larson were based on the " 'necessity of permitting the Government to carry out its functions unhampered by direct judicial intervention.' [This need] is even greater when questions of federalism are involved.") (quoting Larson, 337 U.S. at 704).

132. The district court's decree required the state to fund the operation of Pennhurst, finance the special and hearing masters' offices, and fund the newly created community retardation facilities. For a discussion of federal judicial authority to use state funds in remedying state violations of federal law, see Frug, The Judicial Power of the Purse, 126 U. PA. L. REv. 715 (1978).

133. See Pennhurst II, 465 U.S. at 122 n.32 ("In cases of ongoing oversight of a state program that may extend over years, as in this case, the federal intrusion is likely to be extensive . . . . Here, the federal courts effectively have been undertaking to operate a major state institution ....."); id. at 107 ("According to the dissent, the relief sought and ordered here-which in effect was that a unajor state institution be closed and smaller state institutions be created and expansively funded-did not operate against the State. This view would make the law a pretense.").

134. The Pennhurst II Court quoted from Rizzo when it wrote:

We do not decide whether the District Court would have jurisdiction . . . to grant prospective relief on the basis of federal law, but we note that the scope of any such relief would be constrained by principles of comity and federalism. "Where, as here, the exercise of authority by state officials is attacked, federal courts must be constantly mindful of the "special delicacy of the adjustment to be preserved between federal equitable power and State administration of its own law.'"

Pennhurst II, 465 U.S. at 104 n.13 (quoting Rizzo v. Goode, 423 U.S. 362, 378 (1976), which in turn quoted Stefanelli v. Minard, 342 U.S. 117, 120 (1951)). One author speculates that this language may mean that the Court will expand its eleventh amendinent doctrine (as opposed to relying on the more more flexible principles announced in Rizzo) to bar completely institutional reform suits. See Lee, Sovereign Immunity and the Eleventh Amendment: The Uses of History, 18 URBAN LAw. 519, 545 (1986). 
To be sure, there is language in Pennhurst II suggesting that the eleventh amendment bars all relief, not just institutional reform decrees, based on state law. ${ }^{135}$ A cursory look at the Court's brief discussion of Siler-to the effect that the considerations of policy underlying Siler are subordinate to the explicit limitation on jurisdiction in the eleventh amendment-might suggest that Pennhurst II eliminated pendent jurisdiction altogether for suits against state officials. But in the context of this case, which involved a detailed affirmative decree and in which federal officials took over much of the discretionary decisioninaking for the state institution, it seems inore likely that the Court's concern centered, as it should, on the impact of such decrees on state sovereignty.

II

\section{Limiting PENNHURST II to SUITS SEekINg Institutional Reform}

I have argued that the Court's opinion in Pennhurst II permits, and may actually support, an eleventh amendment distinction based on the nature of the relief sought for pendent state claims. ${ }^{136}$ That is, Pennhurst II may preserve the Siler doctrime for noninstitutional relief cases.

Whether or not the Court actually intended to inake such a distinction, I think the distinction should be made. ${ }^{137}$ This conclusion rests on an evaluation of both the importance of pendent jurisdiction and the relative threat pendent claims pose to state sovereiguty in noninstitutional and institutional reform cases.

First, there are important constitutional and congressional policies favoring the exercise of pendent jurisdiction. Although pendent jurisdiction would advance these policies in both institutional and noninstitutional cases, it is relatively more important in the latter context. Second, institutional reform cases pose a inuch greater threat to state sovereignty than do noninstitutional cases. In institutional reforin cases, federal judges set state priorities, effectively gain access to the state treasury, and displace state inanagement authority over the institution. In noninstitutional cases, which inay involve, for example, a negative injunction barring enforcement of a statute, federal judges neither displace state manageınent and policyınaking authority nor siguificantly burden the

135. See supra note 104.

136. See supra text accompanying notes 102-35.

137. It should be evident that $I$ accept the eleventh amendment doctrine established by the Court prior to Pennhurst II, as well as that case's narrow holding that the eleventh amendment bars institutional reform relief based on state law. Some judges and commentators have posed a more fundamental challenge to the Court's eleventh amendment doctrine. See, e.g., Atascadero State Hosp. v. Scanlon, 473 U.S. 234, 247 (1985) (Brennan, J., dissenting); Gibbons, The Eleventh Amendment and State Sovereign Immunity: A Reinterpretation, 83 CoLUM. L. REv. 1889 (1983); Fletcher, supra note 9. 
state treasury. These differences are magnified in cases in which relief is based on state law.

\section{A. Justifications for Pendent Jurisdiction}

Generally speaking, the federal courts are "courts of limited jurisdiction marked out by Congress." 138 Congress, however, has not provided expressly for pendent jurisdiction. ${ }^{139}$ Lacking explicit congressional guidance, the Court has read the federal question statute ${ }^{140}$ as conferring jurisdiction as broadly as the jurisdictional grant in article III, ${ }^{141}$ and has concluded that article III permits the federal courts to exercise pendent jurisdiction. ${ }^{142}$

Although the Court has found authority for permitting the federal courts to exercise jurisdiction over pendent state claims, it has been somewhat reluctant, in the face of congressional silence, to allow the lower federal courts to employ this type of jurisdiction expansively. ${ }^{143}$ It inay be expected to be even more cautious when a case raises substantial concerns about state sovereignty, for the eleventh ainendment was adopted specifically to protect state sovereignty by himiting federal court jurisdiction. $^{144}$

The Court has recognized a variety of pohicies justifying the exercise of pendent jurisdiction, including the need to avoid piecemeal litigation, to make available a federal forum to adjudicate federal clains, and to

138. Aldinger v. Howard, 427 U.S. 1, 15 (1976).

139. See id. ("Congress was silent on the extent to which the defendant, already properly in federal court under a statute, might be called upon to answer nonfederal questions or claims; the way was thus left open for the Court to fashion its own rules under the general language of Art. III."). There are minor exceptions to this general observation. See, e.g., 28 U.S.C. $\$ 1441$ (c) (1982) (permitting pendent jurisdiction over certain claims when federal claims are removed to federal court); 28 U.S.C. $\S 1338(b)$ (1982) (permitting jurisdiction over state clains of unfair coinpetition when joined to related copyright, patent, plant variety protection, or trademark claims).

140. 28 U.S.C. $\$ 1331$ (1982) ("The district courts shall have original jurisdiction of all civil actions arising under the Constitution, laws, or treaties of the United States.").

141. Article III, $\S 2$ states: "The Judicial Power shall extend to all Cases . . . arising under this Constitution, the Laws of the United States, and [its] Treaties."

142. See Pennhurst II, 465 U.S. at 117 (pendent jurisidiction derives "from the general language of Art. III"); United Mine Workers of Am. v. Gibbs, 383 U.S. 715, 725 (1966) (if the federal and pendent state claims are sufficiently related, "the entire action before the court coniprises but one constitutional "case' ").

143. See Gibbs, 383 U.S. 726-27 (delineating circumstances in which federal courts should decline to consider state claims). When Congress has imposed more explicit linitations on federal jurisdiction, the Court has refused to extend jurisdiction over ancillary claims not covered by the statutory grant. See Owen Equip. \& Erection Co. v. Kroger, 437 U.S. 365 (1978) (in a diversity case, declining to permit ancillary jurisdiction over a claim against a nondiverse third party defendant); Aldinger v. Howard, 427 U.S. 1 (1976) (in a civil rights case, declining to permit ancillary jurisdiction over claims against a "pendent party").

144. See, e.g., Hans v. Louisiana, 134 U.S. 1, 11 (1890). But see Fletcher, supra note 9 (arguing that the eleventh amendment was not intended to prohibit federal court jurisdiction, but to narrow existing language authorizing jurisdiction). 
avoid constitutional questions. Although the Court has not discussed the issue, it is also apparent that pendent jurisdiction allows the federal court to exercise fully its jurisdiction over federal claims.

\section{Avoiding Piecemeal Litigation}

In United Mine Workers of America v. Gibbs, ${ }^{145}$ the Court justified the exercise of pendent jurisdiction on the basis of "considerations of judicial economy, convenience and fairness to litigants." 146 These considerations led the Court im that case to hold that a federal court could exercise pendent jurisdiction so long as the state and federal claims derived "from a common nucleus of operative fact."1 147

Gibbs promotes a policy against piecemeal litigation. ${ }^{148}$ Given the limited resources of botl courts and litigants, it is sensible, if possible, to consolidate state and federal claims raising substantially similar factual issues. All other thimgs (sucl as litigation resources) bemg equal, a policy of consolidatimg related cases n1ay save more judicial and litigation resources $\mathrm{m}$ mstitutional reform suits than im suits for noninstitutional relief; imstitutional reform suits, for example, may well mvolve more protracted disputes over remedies than noninstitutional suits.

Nevertlieless, the desire to avoid piecemeal litigation alone does not compel a doctrime of pendent jurisdiction, for in many cases the efficiency gams for the litigants and courts will be modest. Where the state courts have concurrent jurisdiction over the federal claims, pendent jurisdiction is not necessary to reduce piecemeal litigation; the plamtiff can bring all claims in state court. Even where the federal courts have exclusive jurisdiction over the federal claims, the mcrease in efficiency from pendent jurisdiction nay be limited if the state and federal claims raise identical factual issues. Factual questions litigated im one forum may be binding on the same parties in the other forum. ${ }^{149}$ In addition, pendent jurisdiction does not aid federal "judicial economy." Rather, the state courts

145. 383 U.S. 715 (1966). Gibbs did not involve a claim against either the state or state officials, and thus raised no eleventh amendment issue.

146. Id. at 726.

147. Id. at 725. In the next sentence, the Court framed the test as whether the "plaintiff's claims are such that he would ordinarily be expected to try them all in one judicial proceeding." Id.

148. Although Gibbs also spoke of "faimess to litigants" as a consideration in deciding whether to exercise pendent jurisdiction, $i d$. at 726 , the Court in a later case read that factor as referring to the unfairness to the defendant. See Aldinger, 427 U.S. at 14. Thus, the Gibbs factors supporting pendent jurisdiction may be characterized as "efficiency" concerns.

149. Issue preclusion of matters decided in state court is covered by the Full Faith and Credit Act, 28 U.S.C. $\$ 1738$ (1982) ("The records and judicial proceedings of any court of any . . State ... shall have the same full faith and credit in every court within the United States . . as they have by law or usage in the courts of such State."); see also Allen v. McCurry, 449 U.S. 90 (1980) (issues decided in state court may not be relitigated in subsequent federal action). Although there is no corresponding statute for issues decided in federal court, there is no dispute that the federal 
will have fewer cases, and the federal courts will have more complicated cases. Pendent jurisdiction promotes efficiency no more than a policy encouraging plaintiffs to take all claims to state court. ${ }^{150}$

If in cases between private parties, such as Gibbs, efficiency alone is not a compelling reason for "stretching the constitutional concept of a "case'" in order to extend federal jurisdiction, ${ }^{151}$ it is an even weaker justification when the pendent claim undermines state sovereignty. The eleventh anendment, after all, limits federal jurisdiction in order to protect state sovereignty. The justification for pendent jurisdiction in such cases must be found in other policies.

\section{Providing a Federal Forum}

A stronger justification for pendent jurisdiction derives from the policy, inherent in both Ex parte Young and the federal jurisdictional statutes, of ensuring the availability of a federal forum to vindicate federal rights. Pendent jurisdiction reheves the plaintiff of the pressure to adjudicate both federal and state claims in state court, thus eliminating practical barriers to the plaintiff's choice of a federal forum. ${ }^{152}$

In a number of statutes, Congress has created federal jurisdiction over federal claims, suggesting a congressional policy of giving plaintiffs the choice of litigating their claims in federal court. ${ }^{153}$ Ex parte Young

judgment has preclusive effect on subsequent actions in state court. See $18 \mathrm{C}$. WRIGHT, A. MILLER \& E. COOPER, supra note $7, \S 4468$, at $648-54$.

Regardless of the general rule for issue preclusion, it may be appropriate to make an exception for claims over which the federal court has exclusive jurisdiction, on the ground that according preclusive effect to state court determinations will undercut the purposes underlying Congress's creation of exclusive federal jurisdiction. Nevertheless, several cominentators have concluded that the Court should find a preclusive effect unless there is "clear and manifest" evidence of congressional intent to the contrary. See C. WRIGHT, THE LAW of FEDERAL CGURTS 694 (4th ed. 1983); Currie, Res Judicata: The Neglected Defense, 45 U. CHI. L. REV. 317, 347-48 (1978); see also Will v. Calvert Fire Ins. Co., 437 U.S. 655, 675 (1978) (Breman, J., dissenting) (recognizing that issue preclusion might "Inake sense" for "specific findings of historical facts," but suggesting other reasons for denying preclusive effect); Note, Res Judicata: Exclusive Federal Jurisdiction and the Effect of Prior State-Court Determinations, 53 VA. L. REV. 1360, 1382-83 (1967) (recognizing the importance of giving preclusive effect to factual determinations, but noting that such a policy may undercut the purposes of exclusive federal jurisdiction).

150. In addition, efficiency may be an insignificant consideration in the many cases in which the facts are stipulated. See, e.g., Steffel v. Thompson, 415 U.S. 452, 455 (1974). In those circumstances, bifurcating the federal and state claims would be a relatively minor burden on the litigants and on judicial economy; see also Pennhurst II, 465 U.S. at 122 n.32 (arguing that the goals of efficiency are not advanced when the proper interpretation of state law is uncertain).

151. See P. Bator, P. Mishikin. D. Shapiro \& W. Wechsler, Hart \& Wechsler's The FEDERAL COURTS AND THE FEDERAL SYSTEM 922 (2d ed. 1973) [hereinafter HART \& WECHSLER]; Aldinger, 427 U.S. at 15 (suggesting the same in dicta).

152. See HART \& WECHSLER, supra note 151, at 922-23; Schenkier, Ensuring Access to Federal Courts: A Revised Rationale for Pendent Jurisdiction, 75 Nw. U.L. REv. 245, 251-56 (1980).

153. See, e.g., 28 U.S.C. $\$ 1331$ (1982) (creating general federal question jurisdiction); 28 U.S.C. $\S 1343(3)$ (1982) (creating federal jurisdiction for clains of state violations of federal laws and the 
helped to facilitate that congressional policy. In that case the Court sought to "harmonize the principles of the Eleventh Amendment with the effective supreniacy of rights and powers secured elsewhere in the Constitution"154 by permitting federal suits to enjoin state officers from enforcing unconstitutional state laws. ${ }^{155}$ Young thus reflects a strong pohicy, part statutory and part constitutional, of providing a federal forum for plaintiffs seeking prospective rehef from state violations of the Constitution. ${ }^{156}$

In the abstract, pendent jurisdiction has hittle to do with the availability of a federal forum for federal claims. As the Pennhurst II Court noted, absent pendent jurisdiction a plaintiff may bifurcate his federal and state claims and thus still vindicate federal rights in federal court. ${ }^{157}$

This reasoning, however, ignores the potential practical and legal consequences of ehminating pendent jurisdiction. Where the federal courts have exclusive jurisdiction over federal claims, a plaintiff with limited litigation resources is put to a hard choice: if he carmot afford to hitigate two suits, he is forced to drop either his federal or his state claims. Soine plaintiffs will forgo their federal claims (and foruin), effectively diminislimg the value of the federal right. ${ }^{158}$ Even where jurisdiction is concurrent, giving plaintiffs the additional choice of bringing both federal and state claims in state court, some plaimtiffs will forgo the federal forum in order to raise all claims $\dot{m}$ a smgle suit. As a practical matter, a constitutional prohibition of pendent jurisdiction niakes the federal forum less available.

In addition to practical problems, a plaintiff may run into legal doctrines compelling him to bring all of his claims in state court. In Migra v. Warren City School District Board of Education, ${ }^{159}$ decided the same day as Pennhurst II, the Court held that the Full Faith and Credit Act ${ }^{160}$ requires federal courts to give the saine preclusive effect to federal claims not raised in a state suit that a state court would give to such claims. Because Migra could have, but did not, raise her section 1983 claim im an

Constitution); see also Mitchum v. Foster, 407 U.S. 225, 242 (1972) (stating that the Reconstruction Congress created federal jurisdiction for civil rights claims because it did not trust the state courts to enforce the laws).

154. Pennhurst II, 465 U.S. at 105 (quoting Perez v. Ledesma, 401 U.S. 82, 106 (1971)

(Brennan, J., concurring and dissenting)).

155. See supra text accompanying notes 9-15.

156. See Pennhurst II, 465 U.S. at 105; Young, 209 U.S. at 160.

157. 465 U.S. at 122.

158. It is not surprising that one of the early leading pendent jurisdiction cases was Hurn v. Oursler, 289 U.S. 238 (1933), for that case involved both a copyright claim, for which there is exclusive federal jurisdiction, and a pendent state claim of unfair competition. By allowing the federal court to hear the pendent state claim, the Court promoted the enforcement of the federal right.

159. 465 U.S. 75 (1984).

160. 28 U.S.C. $\S 1738$ (1982). 
earher suit in state court, the federal court was barred from later hearing the claim if it determined that the state court would bar such claims. Conceivably, although perhaps implausibly, the Court will apply Migra to cases that are bifurcated as a result of Pennhurst II. ${ }^{161}$ If so, plaintiffs will be under additional pressure to bring all of their claims in state court. ${ }^{162}$

The policy of making available a federal forum is an important argument favoring pendent jurisdiction. It is difficult to determine, however, whether the availability of pendent jurisdiction will have a greater impact in institutional reform or noninstitutional suits. Because institutional reform suits tend to be inore complex and demand more litigation resources than suits for negative injunctions, institutional reform plaintiffs may feel greater economic pressure to bring all claims in state court. At the same time, institutional reforn plaintiffs (or more precisely, their lawyers) may feel more strongly than other plaimtiffs that the relief they seek is more readily available in federal court.

\section{Avoiding Constitutional Questions}

If, as in the Pennhurst litigation, the plaintiff's constitutional and state claims are alternative bases for relief, exercising pendent jurisdiction may permit the federal court to avoid deciding constitutional questions. ${ }^{163}$ First set forth clearly in Siler v. Louisville \& Nashville Railroad

161. Where the Court has required abstention on state issues, it has indicated that the state court litigation does not preclude relitigation of facts essential to the federal issues in federal court. See Allen v. McCurry, 449 U.S. 90, 101 n.17 (1980); England v. Louisiana State Bd. of Medical Examiners, 375 U.S. 411, 416-17 (1964). Thus, by analogy, Migra may not apply to cases bifurcated as a result of Pennhurst $I I$.

162. See Brown, supra note 99, at 352; Shapiro, supra note 51, at 80-81; Smith, Pennhurst v. Halderman: The Eleventh Amendment, Erie and Pendent State Law Claims, 34 Buffalo L. Rev. 227, 275-81 (1985).

Instead of applying Migra to bifurcated claims, the Court may modify abstention doctrine to require plaintiffs to litigate their state claims in state court before proceeding on their federal claims in federal court, effectively forcing many plaintiffs to bring all claims in state court. Although not required under existing decisions, this version of abstention is compatible with existing doctrine. First, abstention would permit the federal court to postpone, and perhaps avoid, constitutional adjudication by giving the state courts the first opportunity to remedy institutional conditions under state law. The state remedy could obviate the need for federal litigation. See Pennzoil Co. v. Texaco Inc., 107 S. Ct. 1519, 1526-27 (1987).

Second, Younger established the principle that the federal government, "anxious though it may be to vindicate and protect federal rights and federal interests," should "not unduly interfere with the legitimate activities of the States." Younger v. Harris, 401 U.S. 37, 44 (1971). If the plaintiff had initiated state proceedings, parallel federal proceedings could be disruptive, either because the state and federal decrees might be inconsistent, or because there would be two centers of remedial authority competing for the same resources. Even if the plaintiff initially declined to pursue his state remedies, the Court might conclude that proper regard for federalism requires that the states, through state corrective processes, be given the first opportunity to address institutional shortcomings.

163. Pendent jurisdiction is by no means the only device to avoid deciding constitutional 
Co., ${ }^{164}$ this policy of restraint has been considered central to the proper working of constitutional adjudication. ${ }^{165}$

A basic reason for avoiding constitutional questions where possible is that constitutional adjudication is antidenocratic. ${ }^{166}$ It reduces the role of pohtically accountable institutions in making social policy, both by preeinpting political decisionmaking and by being largely immune from reconsideration by the pohtical branches. For the same reasons, unrestrained social reform in the name of constitutional decisionmaking begins to undermme the perceived legitimacy of the federal courts and thus their practical ability to command respect for their judgments in controversial cases. Although many constitutional decisions, even unpopular ones, will not injure the courts' authority to enforce their reading of the Constitution and may even enhance it, the cumulative impact of routine judicial imtervention in the pohtical process risks undercutting the political support that courts require to enforce their mandates. ${ }^{167}$ As a result, courts should be sensitive to the "gravity and delicacy" of such decisions. ${ }^{168}$

In addition, decisions modifying or expanding federal constitutional doctrime often have a much wider impact than decisions based on state statutory or constitutional provisions. A Supreme Court decision defining a federal constitutional right affects similarly situated persons throughout the Umited States, brings into doubt or upholds the vahdity of a range of state and federal statutes, and causes shifts im related or coinpeting constitutional doctrimes. Such a decision may form the basis upon which lower federal courts define the constitutional rights of other classes of persons. Even a district court decision on a constitutional question may influence similar hitigation im other districts. A state statu-

questions. See Ashwander v. Tennessee Valley Auth., 297 U.S. 288, 346-48 (1936) (Brandeis, J., concurring) (setting forth seven "rules" for avoiding constitutional questions, including the Siler rule).

Of course, the availability of pendent jurisdiction does not mean that in practice a federal court will avoid the constitutional questions. In the Pennhurst hitigation, for example, the district court based injunctive relief on both constitutional and pendent state grounds.

164. 213 U.S. 175 (1909).

165. In Siler, the Court wrote that a federal court cannot disregard the state issue in favor of the constitutional issue "without innortant reasons." Id. at 193; see also Pennhurst II, 465 U.S. at 117 (a court usually should resolve a ease on the basis of a pendent claim "in order to avoid federal constitutional questions"). Until Pennhurst $I I$, the Court had given little indication what might constitute "important reasons."

166. See A. Bickel, The Least Dangerous Branch 128 (1962) (characterizing constitutional adjudication as "at least potentially a deviant institution in a democratic society").

167. See A. Bickel, The Supreme Court aNd the IdeA of Progress 94-95 (1970); J. Choper, Judicial Review AND The National Political Process 129-70 (1980); United States v. Richardson, 418 U.S. 166, 188-93 (1974) (Powell, J., concurring). But see J. ElY, DEMOCRACY AND DISTRUST 47-48 (1980) (arguing that neither the Court's prestige nor its power suffers from making constitutional decisions).

168. Ashwander v. Tennessee Valley Auth., 297 U.S. 288, 345 (1936) (Brandeis, J., concurring). 
tory decision, by contrast, need affect only a single provision (or perhaps identically worded provisions) within a single state. Even a state constitutional decision, with its potential to affect a variety of state statutes, is limited to a single state.

Siler's command to decide pendent state issues generally achieves these goals in noninstitutional cases. A decision based on state law does not preempt or displace the power of state political institutions to make substantive policy. If the state legislature disagrees with the federal court's interpretation of state law, it is free to ainend the law to make its meaning clearer.

In institutional reforn cases, the Siler doctrine is less successful in achieving its goal of preserving the primacy of the political branches in policymaking. The state legislature often is unable to reassert its policymaking authority in institutional reforun cases because its principal means of making policy, enacting legislation, is too blunt an instruinent. In many cases, the legislature will disagree, not with the federal court's interpreting state law to create individual rights and corresponding institutional obligations, but with the numerous discretionary choices the judge makes in formulating the decree. ${ }^{169}$ Consequently, amending state law will not shift policymaking authority back to the legislature. The legislature could displace the federal court's decision by repealing the statute, but it may be loathe to do so because it supports the original statute; it is the particular implementation of the statute to which the legislators object. Even if an amendment could set the federal court straight, state officials may be unwilling to unscramble a partially implemented decree, in part because they cannot "unspend" money already spent on reforins, and in part because they may conclude that more harin would occur (because of delay or disruption) by removing federally ordered reforin.

Although institutional decrees based on pendent state claims do not entail all of the drawbacks of a constitutionally based decree, these two types of decisions are alike $m$ their invulnerability to legislative reconsideration. Moreover, each imposes significant costs on state sovereignty by shifting the discretionary authority to manage state institutions from state to federal officials. ${ }^{170}$ As a result, there is comparatively little advantage in avoiding constitutional questions in institutional reforin cases.

\section{Exercising Federal Jurisdiction}

In addition to these bases for exercising pendent jurisdiction, which

169. See Chayes, supra note 114 , at 46 (there is no "unique remedial regime that follows ineluctably from and is measured by the determination of substantive liability").

170. See infra text accompanying notes 180-207. 
the Pennhurst II Court histed but did not discuss, there is a fourth reason that pertains especially to noninstitutional cases: Pendent jurisdiction may be necessary to the exercise of federal jurisdiction.

This argument for pendent jurisdiction may be illustrated by considering a challenge to a state environinental regulation imposing affirmative or financial obligations as a result of conduct that occurred before the enabling statute's enactment. Hoping to avoid a state court determination of his federal rights, ${ }^{171}$ the plaintiff seeks a federal imjunction enjoining enforceinent of the regulation on the grounds that (1) the retroactive apphication of the regulation violates the federal constitution; (2) the regulation, when properly interpreted, does not cover the plaintiff's conduct; (3) the regulation is unconstitutional under state law; and (4) the regulation was not properly enacted under state law.

Applying a broad reading of Pennhurst II to this suit for a negative injunction, the federal court would first dismiss claims (2), (3), and (4), the pendent state claims. After dismissing the state clamis, the federal court would construe, or find a state court construction of, the regulation in order to decide the federal question. Three different things might happen. First, the court might construe the regulation to apply to the plaintiff, and hold that so construed it was constitutional. The state could then proceed with the state court hitigation. Second, the court might find the regulation apphicable to the plaintiff, but hold it unconstitutional, thus barring further state court hitigation under this interpretation of the regulation. In both cases, the plaintiff would have had an opportuinty to vindicate his federal rights in federal court. Neither of these outcomes deprives the federal court of jurisdiction to decide the case.

But consider a third possibility-that the federal court beheves the state regulation, properly construed, does not cover the plaintiff's conduct. For exainple, the court might conclude that the state legislature did not intend to apply the regulatory statute retroactively. Under Pennhurst II, the federal court would be barred from enjoining enforcement of the state regulation because it could not base rehief on state law. In addition, having decided that the regulation does not apply to the plaintiff, the federal court would be obligated to dismiss the suit because the case would no longer present a justiciable federal question. The court would have no authority to review alternative, perhaps unconstitutional,

171. If the state authorities initiate state court proceedings "before any proceedings of substance on the merits have taken place in the federal court," the Younger line of cases bars federal relief. Hicks v. Miranda, 422 U.S. 332, 349 (1975). As a result, there unay be few cases in which both the threat of state enforcennent proceedings are sufficiently real to create an actual controversy under art. III, see Steffel v. Thoinpson, 415 U.S. 452, 458.60 (1974), and the state has not initiated proceedings quickly enough to bar federal litigation under Younger. Nevertheless, the fact that a broad reading of Pennhurst $I I$ would permit this unwarranted anomaly in noninstitutional cases supports liniting the holding in that case to suits for institutional reform relief. 
interpretations since such decisions would violate the fundamental rule agamst advisory opinions. Thus, the plaintiff would have no remedy in federal court.

The state court, however, is not bound by the federal court's interpretation of the state statute, and it may read the statute as applying to the federal plaintiff. ${ }^{172}$ If the state begins an enforcenent action, the Younger line of cases will bar a subsequent federal suit to enjoin the state proceedings and decide the resulting constitutional issues. ${ }^{173}$ Consequently, the federal claim nay well be decided in state court. Although the defendant inay seek Supreme Court review of the federal constitutional issue, ${ }^{174}$ he will not have had the opportunity, as Congress apparently contemplated, to have a federal district court find the facts and decide the federal questions.

A federal court cannot ensure its ability to exercise jurisdiction over the federal claim by invoking Pullman abstention for a state court determination of the state law issues. In many cases, Pullman abstention is not available because the proper interpretation of state law may appear to be relatively clear. ${ }^{175}$ If the federal court is confident of its interpretation of state law, abstention is inappropriate and it inust dismiss the suit. Even assuming the federal court properly abstains under Pullman, a deserving plaintiff nevertheless inay be unable to obtain relief if the state court will not, or caunot, decide the state issue. ${ }^{176}$ Although the entire case would return to federal court, ${ }^{177}$ a broad readimg of Pennhurst II would bar the federal court, as before, froin granting rehef.

This problem-the mability to ensure federal jurisdiction over federal claims-does not arise if the federal court could exercise pendent jurisdiction. ${ }^{178}$ Returning to the hypothetical example, the federal court

172. See, e.g., Dombrowski v. Pfister, 380 U.S. 479, 491 \& nn. 6-7 (1965); see also Shapiro, State Courts and Federal Declaratory Judgments, 74 Nw. U.L. REv. 759, 768-70 (1979).

173. See, e.g., Younger v. Harris, 401 U.S. 37 (1971) (criminal prosecution); Huffman v. Pursue, Ltd., 420 U.S. 592 (1975) (public nuisance suit to close a movie theater).

174. See 28 U.S.C. § 1257(2) (1982).

175. See Hawaii Hous. Auth. v. Midkiff, 467 U.S. 229, 236 (1984) ("Pullman abstention is limited to uncertain questions of state law . ...").

176. Sec Field, supra note 23, at $1146 \&$ n.202 (noting that some states bar their courts from ruling on state law issues unless they have the power to dispose of the entire case).

177. The Pullman doctrine provides that in such circumstances the federal court has jurisdiction to decide the state law issues. See Louisiana Power \& Light Co. v. City of Thibodaux, 360 U.S. 25, 29 (1959).

178. An alternative solution would be to rely by analogy on Pullman abstention to permit the federal court to retain jurisdiction, even though it finds state law inapplicable to the federal plaintiff. Although Pennhurst $I I$ wonld bar the court from granting injunctive relief on this ground, the court night retain jurisdiction in case state courts later interpret state law as applying to the federal plaintiff. If the litigation to this point constitutes federal "proceedings of substance on the merits," Hicks v. Miranda, 422 U.S. 332, 349 (1975), the Younger line of cases may not block the federal court from addressing the federal claims. 
could enjoin enforcement of the environmental regulation on the ground that it does not apply to the plaintiff. If a later state court decision makes it clear that the federal court misinterpreted the regulation, and that the regulation does apply to the plaimtiff, the federal court can reopen the case to consider the remaining state claims, and if need be, the constitutional claim. ${ }^{179}$ Federal jurisdiction over the federal claim is ensured, but only because the federal court could grant rehef on the pendent state claims.

This particular need for pendent jurisdiction rarely will arise in institutional reform cases. The constitutional questions in such cases usually are "in parallel" with the state law questions. That is, the state and federal grounds are alternative bases for rehef; the constitutional issues turn on institutional conditions, not on the proper construction of state law. Because the federal court can go directly to the federal issues, Pennhurst II presents no bar to exercismg federal court jurisdiction. Noninstitutional cases, by contrast, have at least some state issues "in series" with federal issues. Because the federal court must interpret state law before it can reach the federal questions, pendent jurisdiction is necessary to ensure that the federal court always can exercise its jurisdiction over federal claims.

\section{B. The Impact of Institutional and Noninstitutional Relief on State Sovereignty}

In shaping eleventh amendment doctrime, in short in deciding whether a certain type of suit is "against the state," the Court gauges both the need for federal jurisdiction and the extent to which it will coinpromise state sovereiguty. For example, the Court has held the eleventh amendinent bars suits naming the state or a state agency as a defendant, ${ }^{180}$ but makes an exception for certam suits naming state officials. ${ }^{181}$ The poimt is not that such suits are not really suits "against the state," but rather that the exception is necessary to proinote the pohicy of making a federal forum available to vindicate federal rights. ${ }^{182}$ Another example is the distinction the Court has drawn between suits involving retroactive rehef and those involving prospective rehef. In Edelman v.

179. In some cases, the Court has structured federal decrees based on state law to permit the parties to reopen the federal case if the state courts later interpret the state law differently. See Lee v. Bickell, 292 U.S. 415, 426 (1934); Wald Transfer \& Storage Co. v. Smith, 290 U.S. 602 (1933); Glenn v. Field Packing Co., 290 U.S. 177, 178-79 (1933); see also Field, supra note 23, at 1094 n.90 (arguing that even if the decree omits such a provision, the federal court may modify the decree when the state court "has authoritatively spoken").

180. See, e.g., Alabama v. Pugh, 438 U.S. 781 (1978) (federal suit barred absent state consent).

181. See, e.g., Ex parte Young, 209 U.S. 123 (1908).

182. See Pennhurst II, 465 U.S. at 105; see also supra text accompanying note 15. 
Jordan, ${ }^{183}$ the Court held that the eleventh amendment bars suits naming state officials when the rehief is a monetary award from the state treasury. ${ }^{184}$ Had the Court not drawn such a distinction, either the eleventh amendment or Ex parte Young would be a dead letter. ${ }^{185}$

Institutional reform suits have an especially great impact on state sovereignty, and thus raise eleventh amendment concerns. These cases have become an important vehicle by which public interest organizations press for far-reaching structural changes in governmental institutions. ${ }^{186}$ Born out of the desegregation hitigation in the 1950's and 1960's, ${ }^{187}$ suits for affirmative imjunctions were virtually unknown when the Court decided Ex parte Young. ${ }^{188}$

Typically, such suits charge that state custodial institutions, such as prisons and mental institutions, do not comply with affirmative statutory or constitutional obligations. The plaintiffs' lawyers seek to reform these institutions through detailed injunctions specifymg the type, quantity, and quality of services the institution must provide. ${ }^{189}$ Upon finding that institutional conditions violate statutory and constitutional provisions, the district court frequently creates a small bureaucracy consisting of special masters and a professional staff to manage the institution and make the day-to-day decisions necessary for interpreting and implementmg the decree. ${ }^{190}$

183. 415 U.S. 651 (1974).

184. Id. at 677. In some cases, prospective relief requires the expenditure of substantial amounts of state funds. The Court has upheld the relief in such cases even though it is intended to have a remedial effect. See id. at 668 (calling this "ancillary effect . . . a permissible and often inevitable consequence" of Ex parte Young); Milliken v. Bradley, 433 U.S. 267, 288-90 (1977) (upholding district court order for state to pay costs of a remedial educational program).

185. The Pennhurst II Court also recognized this tension. See 465 U.S. at 106 ("Edelman's distinction between prospeetive and retroactive rehef fulfills the underlying purpose of Ex parte Young while at the same time preserving to an important degree the constitutional immunity of the States."). The Court has favored prospective relief because retroactive relief would have a greater disruptive impact on state programs, Edelman, 415 U.S. at $666 \mathrm{n.11}$, and because prospective relief is more critical than compensation in vindicating the federal rights derived from the fourteenth amendment. See Green v. Mansour, 106 S. Ct. 423, 426 (1985).

186. See Diver, supra note 26, at 45 ("Parties have used litigation less as a method for authoritative resolution of conflict than as a means for reallocating power."); Ferleger \& Boyd, AntiInstitutionalization: The Promise of the Pennhurst Case, 31 STAN. L. REV. 717 (1979) (describing the authors' use of hitigation to achieve their goal of deinstitutionalizing Pennhurst).

187. See Fiss, supra note 26, at 2-4. The first Supreme Court decision approving structural relief in a desegregation case did not come until 1971 in Swann v. Charlotte-Mecklenburg Bd. of Educ., 402 U.S. 1 (1971).

188. See Ex parte Young, 209 U.S. 123, 158 (1908) ("There is no doubt that the court cannot control the exercise of the discretion of an officer. It can only direct affirmative action where the officer having some duty to perform not involving discretion, but merely ministerial in its nature, refuses or neglects to take such action.").

189. See Chayes, supra note 26, at 1298-302; Diver, supra note 26, at 49-64; Fiss, supra note 26, at 27-28; Fletcher, supra note 26, at 637-41.

190. For a brief description of the special master's responsibilities in the Pennhurst case, see 
The structural reform decree eviscerates state discretionary authority because the remedy is disconnected from the right; ${ }^{191}$ there is no "unique renedial regime that follows ineluctably froin and is measured by the determination of substantive hability."192 Consequently, the judge's discretion in fashioning rehef is "draniatically enhanced,"193 invariably with a loss of state autonomy in managing the state institution. ${ }^{194}$

Institutional reform suits also threaten state sovereignty by putting state nionies at the disposal of federal judges. ${ }^{195}$ Through its decree, the court requires the state to pay for new progranis, as well as for the federal officials who design and implement these programs. One important consequence is that the state must reallocate state funds, generally at the expense of other individuals, social welfare programs, and institutions not represented in court. ${ }^{196}$

The federal court's interference with state autonomy is heightened when the institutional reform decree is based on a pendent state claim. Often, a federal judge will be less sensitive than a state judge to the nuances of state legislative policy. In devismg an injunctive decree, the federal judge will look only to the statutory provisions and will overlook the cold legislative judginent that gives operative meaning to the statute-the actual appropriation of funds to operate the institution. In reality, the substantive rights conferred by state law are a combimation of statutory provisions and appropriations to implenient those provisions. ${ }^{197}$ Whereas the federal judge has limited mcentive and ability to weigh competing state concerns carefully, ${ }^{198}$ a state judge is more likely

supra note 39; see also Note, supra note 2 (describing the implementation of a detailed injunctive decree reforming Alabama's inental health facilities).

191. See Chayes, supra note 26, at 1293.

192. Chayes, supra note 114 , at 46 .

193. Id.

194. For this reason, the Pennhurst II Court wrote that even relief based on federal law, which normally would be permitted under Ex parte Young, "would be constrained by principles of coimity and federalisin." 465 U.S. at 104 n.13.

195. See Frug, supra note 132, at 716 n.5, 743-57; see also Harriman \& Straussinan, Do Judges Determine Budget Decisions: Federal Court Decisions in Prisons Reform and State Spending for Corrections?, 43 PUB. ADMIN. REV. 343, 348 (1983) (federal suits challenging overcrowded prison conditions have caused state legislatures to increase prison budgets).

196. See Nightline: Wrongfully Institutionalized-and Forgotten at 4-5 (ABC television broadcast, Sept. 5, 1985) (transcript on file with author) (Pennsylvania Secretary of Public Welfare, Walter Cohen, commenting that in responding to the court order in Pennhurst the state had to ignore other institutionalized persons in other state institutions); Weinstein, The Effect of Austerity on Institutional Litigation, 6 LAW \& HUMAN BEHAV. 145, 146 (1982) (because resources are scarce, institutional reform remedies "require the redistribution of present services and resources, generally from one poor group to another").

197. As the Pennhurst II Court observed, to "the extent there was a violation of state law in this case, it is a case of the State itself not fulfilling its legislative promises." 465.U.S. at 108-09.

198. See McRedmond v. Wilson, 533 F.2d 757, 766 (2d Cir. 1976) (Van Graafeiland, J., 
to be sensitive to the full meaning of state law.

In principle, state sovereignty means the state is the final arbiter of state laws, ${ }^{199}$ but in practice the federal judge may irrevocably displace state officials in interpreting and implementing state law. If the federal court imposes an interpretation of state law different from that which the legislature originally imtended, there may be insufficient legislative or agency will to change it back. In many institutional reforin suits, agency and legislative officials side with the plaintiffs in order to advance substantive reform goals or to enhance the institution's budget, ${ }^{200}$ or even to avoid responsibility for difficult pohtical issues. ${ }^{201}$ The federal court decision may shift the balance of power, requiring advocates of the old order to take the initiative. Because it often is easier to block legislation than to enact it, the federal court decision makes it difficult to reassert the earhier prevailing view of state law.

Even if they had sufficient political power to do so, state legislators may be unwilling to "reverse" a partially implemented decree. Some legislators will want to avoid the additional delay or disruption entailed by removing the federal court's reforms; others will want to avoid a confrontation with the federal court. ${ }^{202}$

Perhaps most importantly, neither state court decisions reinterpreting state law nor new legislation would allow state officials to reassert

dissenting) ("A Federal judge rearranging a State's penal or educational system is like a man feeding candy to his grandchild. He derives a great deal of personal satisfaction from it and has no responsibility for the results."); Chayes, supra note 26, at 1309 (if "the decree calls for a substantial commitment of resources, the court has little basis for evaluating competing claims on the public purse").

199. See Erie R.R. v. Tompkins, 304 U.S. 64, 79 (1938) (federal court supervision over state law "is an invasion of the authority of the State and, to that extent, a denial of its independence") (quoting Field, J., dissenting in Baltimore \& O.R.R. Co. v. Baugh, 149 U.S. 368, 401 (1893)).

200. See, e.g., Ferleger \& Boyd, supra note 186, at $720-21$ (reporting that a Pennhurst administrator actively sought a structural reform suit); Harriman \& Straussman, supra note 195, at 349 (suggesting that prison administrators, who normally have little political power in the legislature or in the executive branch, use litigation as a means to increase their budgets).

201. See Aldisert, Judicial Expansion of Federal Jurisdiction: A Federal Judge's Thoughts on Section 1983, Comity and the Federal Caseload, 1973 LAw \& Soc. ORD. 557, 562.

202. The Pennhurst litigation provides an example of a state legislature opposing the district court, but in the end bowing to its will. When it created the special master's office, the district court ordered the state's Department of Public Welfare to fund the special inaster's operations. Following the Supreme Court's 1981 decision in Pennhurst $I$ reversing the Third Circuit, the state legislature, at the beliest of the Secretary of the Department of Public Welfare, refused to appropriate the necessary money. When the Departinent in turn refused to pay any money to the special master, the district court held the Secretary and Department in contempt, fining them $\$ 10,000$ for each day of noncompliance. Halderman v. Pennhurst State School \& Hosp., 533 F. Supp. 631, 640 (E.D. Pa. 1981), aff'd, 673 F.2d 628 (3d Cir. 1982), cert. denied, 465 U.S. 1038 (1984). Although the legislature continued to refuse to appropriate money for the special master's expenses, it did permit payment of $\$ 1.2$ million in fines, knowing that the district court was directing those payments to the special master's account. Halderman v. Pennliurst State School \& Hosp., 526 F. Supp. 423 (E.D. Pa. 1981). 
their authority over state pohcy. The basic disagreement between state officials and the federal judge generally is not over the proper interpretation of state law, but over both the degree to which and the means by which the federal judge impleinents state law. Reinterpreting or amending the statute will not shift discretionary authority back to state authorities.

By contrast, noninstitutional rehef based on a pendent state claim does not displace state discretionary authority or reallocate state spending priorities. For example, a suit to enjom enforcement of a state environinental regulation, or the litigation in Siler itself to enjom state officials from enforcing state regulations setting railroad rates, does not require state officials to do something, but ratlier to stop doing something. Of course, every affirmative obligation can be formulated as a negative duty. A court order to provide shower water in a prison at a certain teinperature could be characterized as an order prohibiting sliower water at any otlier temperature. Nevertlieless, there is an important functional distinction between "affirmative" and "negative" injunctions that also marks important differences in the impact that the relief has on state sovereignty. ${ }^{203}$

Siler and Pennhurst illustrate this distinction. In Siler the injunction prevented state officials from enforcing the state railroad rate regulations, but it did not coinpel them to create new regnlatory programs, spend state resources, or exercise tlieir discretion in any particular fashion. Nor did the decree permit federal officials either to assume responsibility for managing a state program or institution, or to relegate state officials to subordinate positions in the federal bureaucracy. Unlike the district court decree in Pennhurst, Siler did not shift discretionary autliority-in short, political power-from state to federal authorities. ${ }^{204}$

203. The one exception to the distinction between affirmative and negative injunctions that comes to inind is a suit challenging the constitutionality of a state tax system. Both Congress and the Court have made clear that the negative injunctions sought in these suits pose such large threats to state autonoiny that they must be heard in state court unless the state court reinedy is inadequate. See Tax Injunction Act, 28 U.S.C. $\$ 1341$ (1982 \& Supp. III 1985) (prohibiting federal district courts from interfering with assessinent, levy, or collection of state taxes); Great Lakes Dredge \& Dock Co. v. Huffman, 319 U.S. 293 (1943) (discussing scope and purposes of the Tax Injunction Act); see also Fair Assessment in Real Estate Ass'n, Inc. v. McNary, 454 U.S. 100, 102-03 (1981) ("Congress also recognized that the autonony and fiscal stability of the States survive best when state tax systems are not subject to scrutiny in federal courts. ... This legislation, and the decisions of this Court which preceded it, reflect the fundamental principle of coinity between federal courts and state governments that is essential to 'Our Federalisin,' particularly in the area of state taxation.").

204. See also Ex parte Young, 209 U.S. 123, 159 (1908) (naking the point that negative injunctions, as compared with affirmative decrees, do not interfere with the discretion of state officers).

The distinction between affirmative and negative decrees also may dennarcate those issues a federal court is most capable of addressing. See D. Horowirz, The Courts and Social Policy 19 (1977) ("[T] here is a difference between foreclosing an alternative and choosing one, between constraining and colnmanding. Anong other things, it is this difference, and the problematic 
It goes too far to say that noninstitutional rehef based on state law does not interfere at all with state sovereignty; it does, but only to a limited extent. First, it blocks enforcement of a state law. Although this effect can be significant, it is much less significant than the impact of an affirmative decree reallocating state resources and blocking state officials from exercising their discretionary authority in managing state institutions.

Second, a negative decree requires the federal court to interpretand thus to soine extent to displace state officials from interpretingstate law. Interpreting state law, without more, normally poses only relatively modest federalism problems. In diversity and pendent jurisdiction cases between private parties, federal courts routinely interpret state law without any suggestion that the state's autonomy is at risk. ${ }^{205}$ When the Court has required abstention, its aim usually has been to avoid premature decision of constitutional questions rather than to protect state autonomy. ${ }^{206}$

Even when the defendant is a state official, the threat to state sovereignty posed by negative decrees is modest. If state law is unclear, the court may abstain to permit a state court to provide an authoritative interpretation. If the court does not abstain, its interpretation of state law is not binding on state courts. After the plaintiff obtains a federal court order enjoining enforcement of the regulation, the state should be able to seek a state court interpretation that will be both definitive and binding on the federal court. Indeed, to preserve this opportunity, the Court has required federal decrees based on state law to provide explicitly that the parties may move to reopen the case if a state court later interprets state law differently than did the federal court. ${ }^{207}$ Thus, federal judicial power to decide pendent state claims may displace state authority to interpret state laws, but only temporarily.

Finally, the intrusion on state sovereignty that occurs when a federal

character of judicial resources to manage the task of commanding, that make the question of capacity so important.").

205. Professor Field correctly points out, however, that some types of decisions in suits between private parties may bear heavily on important state interests. See Field, supra note 23, at 1142 .

206. See Fornaris v. Ridge Tool Co., 400 U.S. 41, 44 (1970) (per curiam); United Gas Pipe Line Co. v. Ideal Cement Co., 369 U.S. 134, 135-36 (1962); Clay v. Sun Ins. Office Ltd., 363 U.S. 207, 212 (1960). But see Lehman Bros. v. Schein, 416 U.S. 386 (1974) (in a diversity case raising no constitutional questions, the Court remanded to the court of appeals to consider whether certification of state issue to state court is appropriate).

207. See supra note 179. Justice Stevens cited these cases in his dissent in Pennhurst II. See 465 U.S. at 163 n.46. His argument, implicitly, is that relief based on pendent state claims intrudes only modestly on state sovereignty because the state is free to impose its interpretation of state law. Although this argument is correct when applied to noninstitutional cases, it cannot be extended to institutional reform cases. The principal problem is that once a federal court finds the state liable and orders immediate implementation of detailed affirmative relief, the state is unlikely to undo the new program. Such practical barriers do not exist in noninstitutional cases. 
court interprets state law frequently is unavoidable. If the state and federal issues are "in series," as they often are in noninstitutional cases, the federal court inust interpret state law in order to reach the federal question. Barring relief based on pendent claims in noninstitutional cases will not skirt the need to interpret state law.

\section{CONCLUSION}

A broad reading of Pennhurst II would provide an easily administered rule: the eleventh amendment bars relief based on state law. This holding would avoid the ambiguity inherent in cases, such as Lyons, ${ }^{208}$ instructing lower courts to consider the impact of relief on state autonomy in deciding whether to grant equitable rehef.

A broad reading of Pennhurst II, lowever, disregards the importance of pendent jurisdiction and fails to acknowledge that different kinds of relief liave different impact on state sovereignty. Moreover, it would be inconsistent with earlier developments in eleventh amendment doctrine, such as Ex parte Young, in which the Court weighed the intrusion on state sovereignty agamst the importance of exercising federal jurisdiction.

If the Court's principal concern is, as I have suggested, institutional reform hitigation, Pennhurst $I I$ falls far slort of providing a complete doctrinal solution. For example, under long established eleventh amendinent doctrine, Pennhurst $I I$ does not apply to pendent state relief agaimst local officials. ${ }^{209}$ Nor does it bar rehef based on federal law. It is unlikely that the Court would seek to limit federal remedial power over federal claims by extending Pennhurst II; Ex parte Young is too well entrenched.

It is possible to sketch out a different approacl, focusing more directly on the source of the problem - the power of the federal courts to formulate and inplement institutional reform decrees-while giving soine weight to the plaintiff's choice of a federal forum. Ratlier than use the eleventh amendinent to bar consideration of pendent claims, the Court could require federal courts to abstam from granting rehef, relying by analogy on the equitable restraint doctrimes in Rizzo and Lyons. In other words, the federal court would consider claims for declaratory relief on institutional hability (on both federal and state grounds), ${ }^{210}$ but it would abstain to pernit the state courts (or even the state legislature) to formulate and implement appropriate relief. The plaintiff would lave unrestricted access to federal court on the issue of liability, and the fed-

208. 461 U.S. 95 (1983).

209. See, e.g., Lincoln County v. Luning, 133 U.S. 529, 530 (1890) (eleventh amendment not applicable to suits against a county).

210. See supra note 27 (describing declaratory relief satisfying the eleventh amendment). 
eral court would not displace state discretionary authority in formulating relief and setting spending priorities. In order to ensure that state offcials do not abuse their obligation to exercise their discretionary authority responsibly, the plaintiff should be able to return to federal court for "further necessary and proper relief" 211 if state officials failed to act with "due diligence," or perhaps if they acted in "bad faith."

These ideas are only preliminary. It is enough for now to recognize both that Pennhurst II should be read narrowly to achieve its intended purpose, and that there remains ample room for further doctrinal developments. 